\title{
What do cellular responses to acidity tell us about cancer?
}

\author{
Wiktoria Blaszczak ${ }^{1} \cdot$ Pawel Swietach $^{1} \mathbb{1}$
}

Received: 30 September 2021 / Accepted: 22 November 2021 / Published online: 30 November 2021

(c) The Author(s) 2021

\begin{abstract}
The notion that invasive cancer is a product of somatic evolution is a well-established theory that can be modelled mathematically and demonstrated empirically from therapeutic responses. Somatic evolution is by no means deterministic, and ample opportunities exist to steer its trajectory towards cancer cell extinction. One such strategy is to alter the chemical microenvironment shared between host and cancer cells in a way that no longer favours the latter. Ever since the first description of the Warburg effect, acidosis has been recognised as a key chemical signature of the tumour microenvironment. Recent findings have suggested that responses to acidosis, arising through a process of selection and adaptation, give cancer cells a competitive advantage over the host. A surge of research efforts has attempted to understand the basis of this advantage and seek ways of exploiting it therapeutically. Here, we review key findings and place these in the context of a mathematical framework. Looking ahead, we highlight areas relating to cellular adaptation, selection, and heterogeneity that merit more research efforts in order to close in on the goal of exploiting tumour acidity in future therapies.
\end{abstract}

Keywords Metabolism $\cdot \mathrm{pH} \cdot$ Acid-base $\cdot$ Cell lines $\cdot$ Variation $\cdot$ Adaptation $\cdot$ Selection $\cdot$ Evolution $\cdot$ Phenotype

\section{The role of cell lines in cancer research}

The World Health Organization estimates that cancer accounts for one in six deaths globally [1]. This headline figure is the reason for the tremendous and increasingly interdisciplinary research efforts aimed at understanding and treating the disease. The widespread laboratory use of cancer cell lines established from human patients has, beyond doubt, contributed greatly to the relative success of scientific research in improving survival for patients diagnosed with melanoma, Hodgkin lymphoma and breast, prostate, testicular, cervical, and thyroid cancers [2]. Despite emerging concerns and recognised limitations [3-6], cell lines offer a degree of insight into molecular disease mechanisms that is matched by no other available biological resource [7]. As research methods improve in terms of cost-effectiveness, spatiotemporal resolution, sensitivity, and data throughput, it is likely that cell lines will remain a cornerstone of cancer research in the foreseeable future, especially considering the

Pawel Swietach

pawel.swietach@dpag.ox.ac.uk

1 Department of Physiology, Anatomy \& Genetics, Parks Road, Oxford OX1 3PT, England growing consensus for repeating measurements on a wide panel of lines. In light of the so-called reproducibility crisis $[8,9]$ and the perceived failure of many preclinical concepts to succeed in human trials [10], the case for designing informative, relevant, and well-controlled experiments on cell lines has never been more pressing. This ambition can be met by considering clinical observations made on patients and by referring to predictions made by mathematical models which have their roots in ecology.

\section{What cancer patients and mathematical models tell us about the optimal design of experiments using cell lines}

Cancer cell lines carry with them a record of genetic mutations which were ultimately responsible for the neoplastic growth that mandated surgical resection [11]. On excision, the cancer cells lost the unique cellular and humoral context that they grew into, which inadvertently impacts their biological behaviours in vitro. After many months or even years of passages in culture media, cell lines may behave very differently from the original cancer cells and even diverge between different laboratories [12-15]. These issues highlight the importance of two matters pertaining to good 
laboratory practice. Firstly, cell lines must be monitored for characteristic behaviours that verify the retention of key properties of the original cancer cells. Secondly, culture conditions should attempt to mimic the chemical (e.g. ionic composition [16-18]) and physical properties (e.g. matrix stiffness [19-21]) of the tumour [22,23].

Historically, observations made on human cancers have provided essential instructions on how to perform in vitro experiments using cell lines. Over time, these observations have been refined and expanded to include newly described properties. This information includes a description of the hallmarks of cancer [24, 25], which experimental models should strike to retain in order to ensure disease relevance. Additionally, measurements on human tumours have described the physicochemical properties of the tumour microenvironment [26-29], such as the oxygen partial pressure $\left(\mathrm{pO}_{2}\right)[30,31]$ or acid-base balance quantified in terms of $\mathrm{pH}$ [32-35]. For example, elevated lactic acid production has been recognised - for over a century - to be characteristic of tumours, even when adequate oxygen supply would seem to favour oxidative phosphorylation [36]. This hallmark is exploited diagnostically in ${ }^{18} \mathrm{~F}$ fluorodeoxyglucose imaging to identify cancer cells based on their glucose appetite [37-39]. Thus, it is prudent to confirm that the cell lines chosen for studying a particular cancer also phenocopy its metabolic profile [40, 41]. It is equally important to ensure that culture conditions are relevant to the in situ milieu of the relevant tumour of interest. The reference thresholds for experimental conditions have been defined by measurements using invasive probes [42] and imaging of patient tumours [43] or by assays performed on biopsies [44, 45]. While these tasks are conceptually simple with contemporary technology, efforts to define precise thresholds are compounded by variation among patients (exacerbated further by any comorbidity), the spatiotemporal heterogeneity within tumours, and the diversity of metastatic niches. Consequently, it has not been possible to match every commonly used cell line with a bespoke set of growth conditions, although formal guidelines and informal agreements have been implemented in recognition of this issue [46-48].

A central pillar of the scientific process is to study how cells respond to controlled changes in specific factors. This hypothesis-driven, reductionist approach is necessary for ranking the various possible factors that influence cancer progression. However, this strategy raises the critical question of which factor to select as the independent variable for testing. It would be desirable to perform a sensitivity analysis for all known variables, but this is still outside the scope of modern research approaches. Instead, decisions on what factor to vary have often been influenced by historical precedent, methodological constraints, or even personal biases. One approach that can assist in identifying the dominant factors influencing carcinogenesis involves mathematical models that have their origins in studies of interactions between species in an ecosystem [49-52]. Despite some obvious differences between animal and cellular societies, the results of these simulations have laid down priorities for cancer research.

The relationship between cancer cells and normal cells resembles predator-prey interactions, described mathematically using a system of differential equations called the Lotka-Volterra equations [53]. The elegance of these simulations is that they can track the tumour-host interplay over time until one of three scenarios is attained at the equilibrium point (Fig. 1):

(i) extinction of cancer cells, i.e. cancer recedes;

(ii) a stable coexistence of cancer and normal cells, i.e. a benign tumour;

(iii) unconstrained growth of cancer cells leading to the extinction of normal cells, i.e. invasive cancer.

In terms of therapy, it is important to know which trajectory a particular carcinoma will follow because of tangible opportunities for drugs to reroute cellular fates towards the first or at least second outcome. These mathematical models have a distinct advantage over clinical observations and cell line-based experiments in that they are able to 'explore' the process of carcinogenesis from an early stage, provided that there is sufficient data at other time points to best-fit values

\section{Equilibrium point}

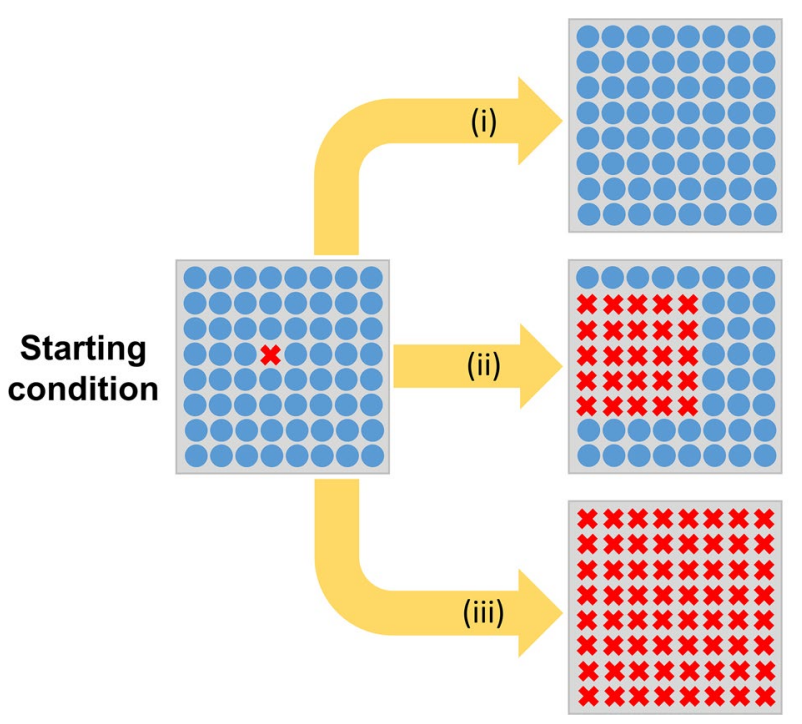

Fig. 1 Predicted outcomes of Lotka-Volterra models. Cancer cells (red-crossed) and normal cells (blue circles) cohabit a tissue ecosystem. With time, the interaction between these cells and their environment can lead to three trajectories that culminate in three different equilibrium points: (i) extinction of cancer, i.e. cancer remission, (ii) stable coexistence, i.e. benign tumour, (iii) cancer cells take over normal cells, i.e. invasive cancer 
to all necessary variables. Insight into this longitudinal process is not normally available by studying patients because many cancers (particularly pancreatic ductal adenocarcinoma [54]) are detectable only as they approach the equilibrium state. In the laboratory, it is not normally possible to follow a system over a sufficiently long time for it to truly attain a steady state because of inherent limitations in the design of in vitro and animal experiments. Moreover, the cell lines established from patients capture the latter part of the carcinogenesis process, giving limited insight into how the cells got to that particular point. In the absence of empirical evidence, mathematical models have been consulted to give a steer on the best strategies to interfere with the early stages of cancer growth. Examples of interventions predicted by mathematical modelling to be effective include those that target one or more of the following (Fig. 2):

a). growth-related interventions that restrict the host's capacity to harbour cancer cells;

b). host defences against cancer cells, such as the immune response;

c). the negative effect that cancer cells exert on host cells, e.g. cancer cell activities that create a harsh microenvironment for the host tissue.

Fig. 2 Effective strategies for cancer therapy predicted by mathematical models. Cancer cells (red-crossed) and normal cells (blue circles) cohabit a tissue ecosystem. A Reducing the capacity of the tissue to carry cancer cells, e.g. with antiangiogenic therapy. B Weakening cancer defence mechanisms against host activities, e.g. immunotherapy. C Preventing cancer cells from generating a harsh environment for the host cells, e.g. influencing the microenvironment (a)

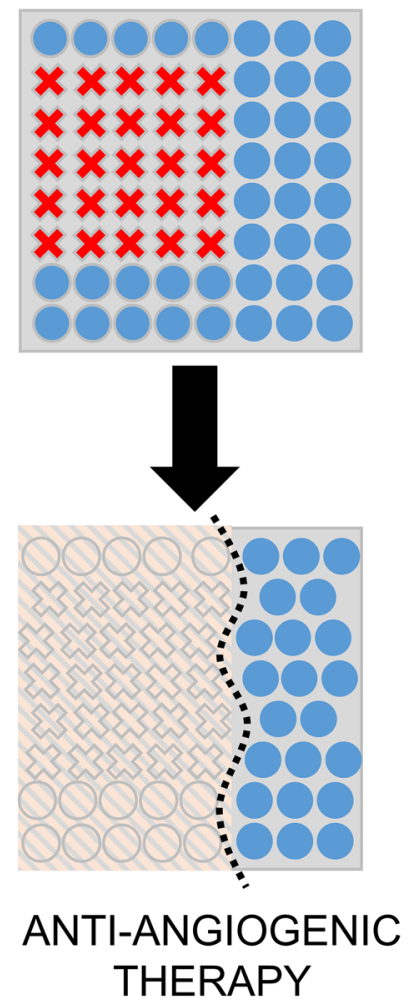

The clinical effectiveness of antiangiogenic therapies and immunotherapy can be explained in terms of their actions on the first and second targets, respectively [55, 56]. The third target is recognised for its untapped therapeutic potential that could be realised by studying the interplay between cell lines and their environment. Frustratingly, the nature of this interplay is still inadequately characterised and, understandably, has not yet achieved the same level of success in clinical trials as antiangiogenics or immunotherapy. Since mathematical models predict synergy between two or more of the above targets, all three targets merit balanced research efforts.

Mathematical models are also useful for predicting the long-term effectiveness of therapies formulated on the basis of promising preclinical results. These simulations have often arrived at counterintuitive conclusions. For example, according to Lotka-Volterra models, therapies that selectively kill the majority of cancer cells cannot, in the end, change overall outcomes. This is because the 'ecosystem' eventually arrives at the same equilibrium point once the surviving population of cancer cells expands [57-59]. In other words, even a small number of surviving cells is able to repopulate tissues and continue along the prior trajectory. (b)
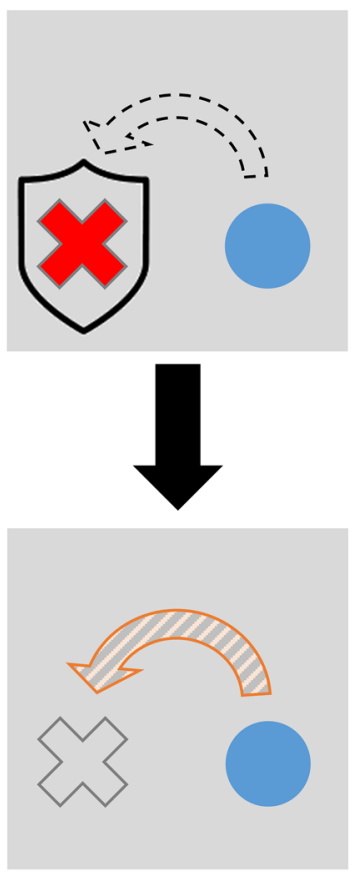

IMMUNOTHERAPY (c)
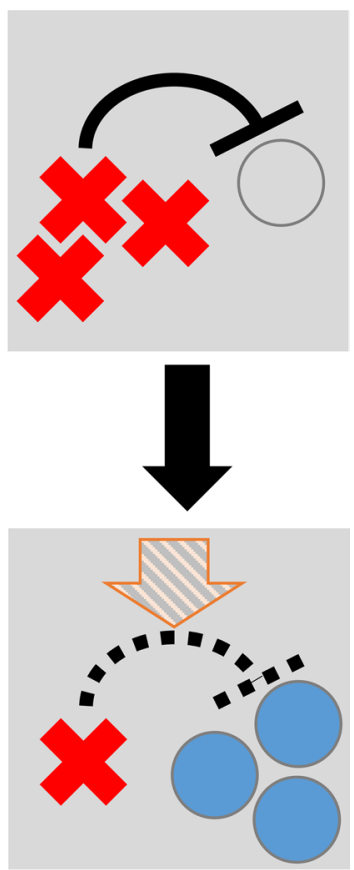

TARGETING THE MICROENVIRONMENT 


\section{The case for studying acidosis in cancer research}

Mathematical predictions highlighting the therapeutic potential of targeting the cell-(micro)environment interplay have reinvigorated efforts to understand how cancer cells influence their surrounding milieu and how this feeds back on cancer and normal cells growing alongside one another. Historically, the two aspects of the harsh tumour microenvironment that have garnered considerable scientific attention are hypoxia and acidosis, ostensibly because of their direct relationship with mitochondrial respiration and glycolytic metabolism, respectively. Cancers cannot grow without an adequately high metabolic rate, thus some combination of lactic acidosis and hypoxia is expected in solid tumours [36, 60-62]. Of these two chemical variables, it is more conceivable to exercise experimental or therapeutic control over the extracellular $\mathrm{pH}$ of tumours (pHe), as compared to $\mathrm{pO}_{2}$; for example, by means of $\mathrm{pH}$ buffering [63] described later. Another argument in favour of targeting $\mathrm{pHe}$ is that the remit of such interventions is largely restricted to the extracellular compartment. This selectivity has the beneficial effect of protecting intracellular $\mathrm{pH}$ (pHi) in noncancerous cells, although some degree of pHi-pHe coupling is inevitable [64]. In contrast, $\mathrm{O}_{2}$ gas permeates freely across membranes; thus, any manipulation to extracellular $\mathrm{pO}_{2}$ will seamlessly transmit across to the intracellular compartment of both cancerous and noncancerous cells [65].

Some of the earliest experiments investigating the effect of pHe on cancer cells were performed by Harry Eagle in the 1970s [66]. His results, using readouts such as proliferation, introduced the concept of a pHe optimum range. A key observation borne from this and many subsequent studies was the steepness of $\mathrm{pHe}$ survival curves for many

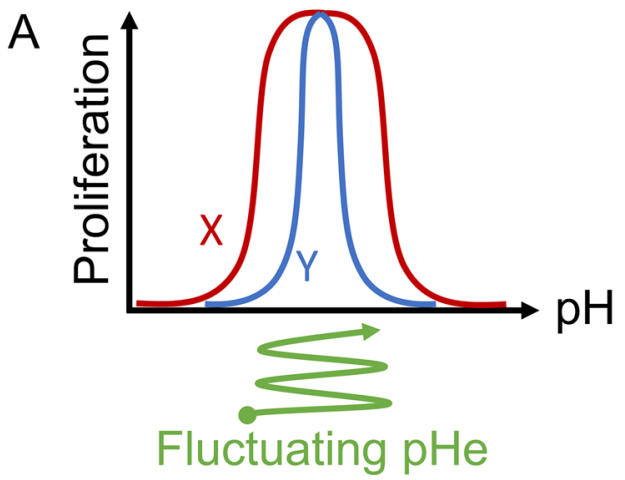

Fig. 3 Examples of $\mathrm{pH}$ sensitivity curve for proliferation. A Cell $X$ has a broader $\mathrm{pH}$ optimum compared to cell $Y$, therefore its survival prospects are higher during fluctuations in $\mathrm{pH}$. Such dynamic changes in $\mathrm{pH}$ have been described in tumours. B Cell $X$ has an acid-shifted cancer cell lines [67]. The reason underpinning this exquisite sensitivity relates to the multitude of protein targets for $\mathrm{H}^{+}$ions. The significance of this observation is that only a small change in pHe is sufficient to produce a meaningful effect on cell behaviours. Thus, among competing cell populations, the shape of their pHe sensitivity curves can have a profound impact on survival prospects. For example, a cell with a broader pHe optimum range would be more successful during fluctuating $\mathrm{pHe}$, as compared to a cell with a narrow pHe optimum range (Fig. 3A). There are also various adaptive strategies based on $\mathrm{pHe}$ sensitivity that could give a competitive advantage to a particular subpopulation of cells. For instance, cancer cells could gain a selective advantage over host cells if their pHe optimum range is shifted towards a more acidic level and, concurrently, their glycolytic output is increased. This combination is expected to reduce pHe to a level that is harsh for host cells but conducive for the adapted cancer cells (Fig. 3B). This strategy relies on the ability of cancer cell populations to change beyond the normal constraints imposed on noncancerous cells. Critically, only minor adjustments to pHe sensitivity may be sufficient to change the trajectory of cancer towards invasive behaviour. By the symmetrical argument, only a small degree of alkalinisation, such as that attainable with therapeutic buffering [68], may be required to steer away from the malignant phenotype.

Changes in $\mathrm{pHe}$ can produce a myriad of consequences on cell biology [69-72] because protonation is a form of posttranslational modification that affects virtually all proteins [73]. Notwithstanding the breadth of potential targets, a subset of proteins has been described as bona fide $\mathrm{pHe}$ sensors, whose primary role is to transduce a pHe signal into a measurable cell response [72]. The discovery process for these sensors has typically taken the approach of mapping

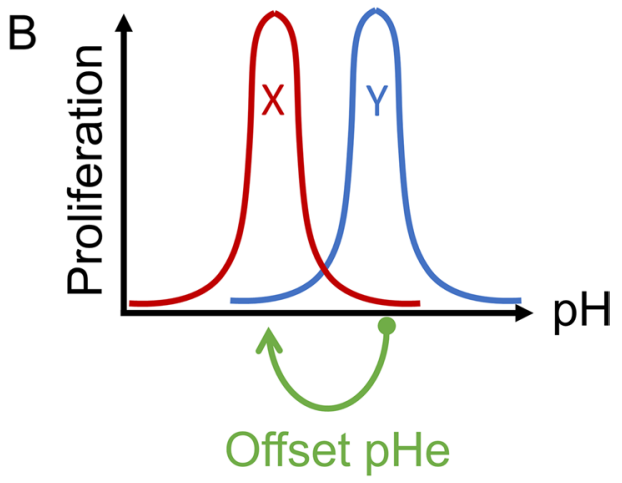

pH optimum compared to cell $Y$. If cell $X$ also has a higher metabolic rate, it is likely to drive tissue pHe to a lower level. This would have the effect of giving cell $X$ a survival advantage over cell $Y$ 
the pHe sensitivity of downstream readouts. For example, the first $\mathrm{H}^{+}$-sensing G-protein-coupled receptor OGR1 was discovered by screening for effects on the second messenger $\mathrm{IP}_{3}$ [74]. These, and many other studies, were biassed by design, in the sense that the hypothesis was testing the pHe sensitivity of an a priori defined target, rather than taking a more agnostic approach towards the identity of the putative $\mathrm{H}^{+}$sensor. To address this concern, recent studies have sought evidence for pHe-sensitive pathways using unsupervised discovery pipelines, such as transcriptomics $[75,76]$, proteomics [76, 77], or metabolomics [78, 79]. The general conclusion from these studies is that a decrease in $\mathrm{pHe}$ triggers a multifaceted response that involves a change in phospholipid composition [79], increases glutaminolysis and fatty acid synthesis [78], induces autophagy [80, 81], remodels the extracellular matrix [75, 82], modulates the cell cycle [75], affects DNA repair [75], promotes epithelial-mesenchymal transition (EMT) [83], and increases alternative splicing [84]. However, when interpreting these results, it is important to consider the precise level of $\mathrm{pHe}$ attained during measurements and how this change was made experimentally. Since $\mathrm{pH}$ is a continuous variable, the measured response must refer to the specific 'test level'. This becomes problematic if $\mathrm{pHe}$ is not noted when data are collected or when pHe is poorly controlled, e.g. is drifting because of ongoing metabolism or if ambient $\mathrm{CO}_{2}$ levels are changed between incubators and bench side assays. There are multiple options for changing the pHe of media, and it is important to relate these to the physiological scenario. Normally, a fall in pHe arises from an increase in $\mathrm{CO}_{2}$ partial pressure (so-called respiratory acidosis) or a decrease in $\left[\mathrm{HCO}_{3}{ }^{-}\right]$due to a buildup of nonvolatile (i.e. non- $\mathrm{CO}_{2}$ ) acids or renal loss of $\mathrm{HCO}_{3}{ }^{-}$ions (so-called metabolic acidosis) [85]. Metabolic acidosis must be accompanied by an increase in the concentration of the anion that stoichiometrically accompanies $\mathrm{H}^{+}$ions (the so-called conjugate base), for example, lactate anions. This organic component may, on its own right, produce cellular responses; indeed, some metabolic responses appear to depend on whether they are evoked by lactic acidosis or acidification paired with a different anion [78]. Thus, the interpretation of acid responses becomes difficult if the study write-up did not explain how pHe was reduced. Substantial differences in the experimental process for changing $\mathrm{pHe}$ can make comparisons between studies difficult or even impossible, especially when apparently contradictory findings are postulated [86, 87]. To avoid these issues, adherence to recently published guidelines is recommended [46].

A large number of studies have documented the actions of acidity on cancer cells. However, many of these reports have not consistently described the method by which $\mathrm{pH}$ had been manipulated or provided a justification for a particular choice of $\mathrm{pHe}[70,71,88-91]$. This is problematic because different strategies for manipulating $\mathrm{pH}$ can produce distinct responses, even if the final $\mathrm{pHe}$ is matching. Table 1 presents a selection of $\mathrm{pH}$-related studies alongside information on how pHe had been changed. The most common way of creating acidic conditions is to exchange $\mathrm{NaHCO}_{3}$-based media with formulations containing nonvolatile buffers, as HEPES and PIPES, followed by titration with strong acids or bases. This can be problematic because media titrated outside $\mathrm{CO}_{2}$ incubators will inevitably acidify in an atmosphere of 5\% $\mathrm{CO}_{2}$, thus compromising $\mathrm{pH}$ control. In a smaller subset of studies, pHe was adjusted by changing the concentration of $\mathrm{NaHCO}_{3}$, a strategy that we argue is most physiologi$\mathrm{cal}$, predictable, and stable. In half of the primary literature reviewed herein, the technique used for adjusting $\mathrm{pH}$ was not reported with adequate detail. The lack of consistent reporting standards continues to be problematic for establishing a unifying model of how acidosis affects cancer cells.

Historically, tumours have been considered acidotic and hypoxic, but this does not imply that regions of low $\mathrm{pO}_{2}$ also have low pHe. Indeed, recent evidence argues for distinct areas of acidosis or hypoxia, each associated with distinct cellular behaviours in situ [84]. At the cellular level, responses to hypoxia tend to be different to those evoked by acidosis, which is consistent with the unique molecular transducers of low $\mathrm{pHe}$ or low $\mathrm{pO}_{2}$ responses $[104,105]$. Very few studies have offered insight on how responses to $\mathrm{pHe}$ are subservient to $\mathrm{pO}_{2}$ [97], and vice versa $[94,106]$. This interaction is highly relevant to our understanding of cancer responses at the interface between two selection pressures, a niche that may favour the most invasive of phenotypes.

\section{Acid-driven selection versus adaptation}

While the pHe sensitivity of cancer cell biology is undisputed, a more controversial issue concerns the level of $\mathrm{pHe}$ that should be considered 'typical' for tumours. Unlike most normal tissues that maintain their interstitial $\mathrm{pHe}$ near 7.4 by means of good capillary perfusion, there is no single value of $\mathrm{pHe}$ that could be considered representative of tumours. MR imaging modalities, ranging from 3-aminopropylphosphonate spectra [107] to CEST [108] have reported tumour pHe to be as low as 6.3 [109], although the spatial resolution of these techniques may inadvertently smoothen steep gradients of $\mathrm{pHe}$ and therefore mask small pockets of profound acidity. A compendium of $\mathrm{pHe}$ measurements using imaging and electrodes is provided in Table 2. This meta-analysis shows that most intratumoural $\mathrm{pHe}$ measurements have been in the range 6.4-7.4, with a median value of 6.8 [110-113]. Accordingly, experiments using cell lines under culture conditions should avoid exceeding these limits. Despite awareness of this concern, there has been a tendency for in vitro 


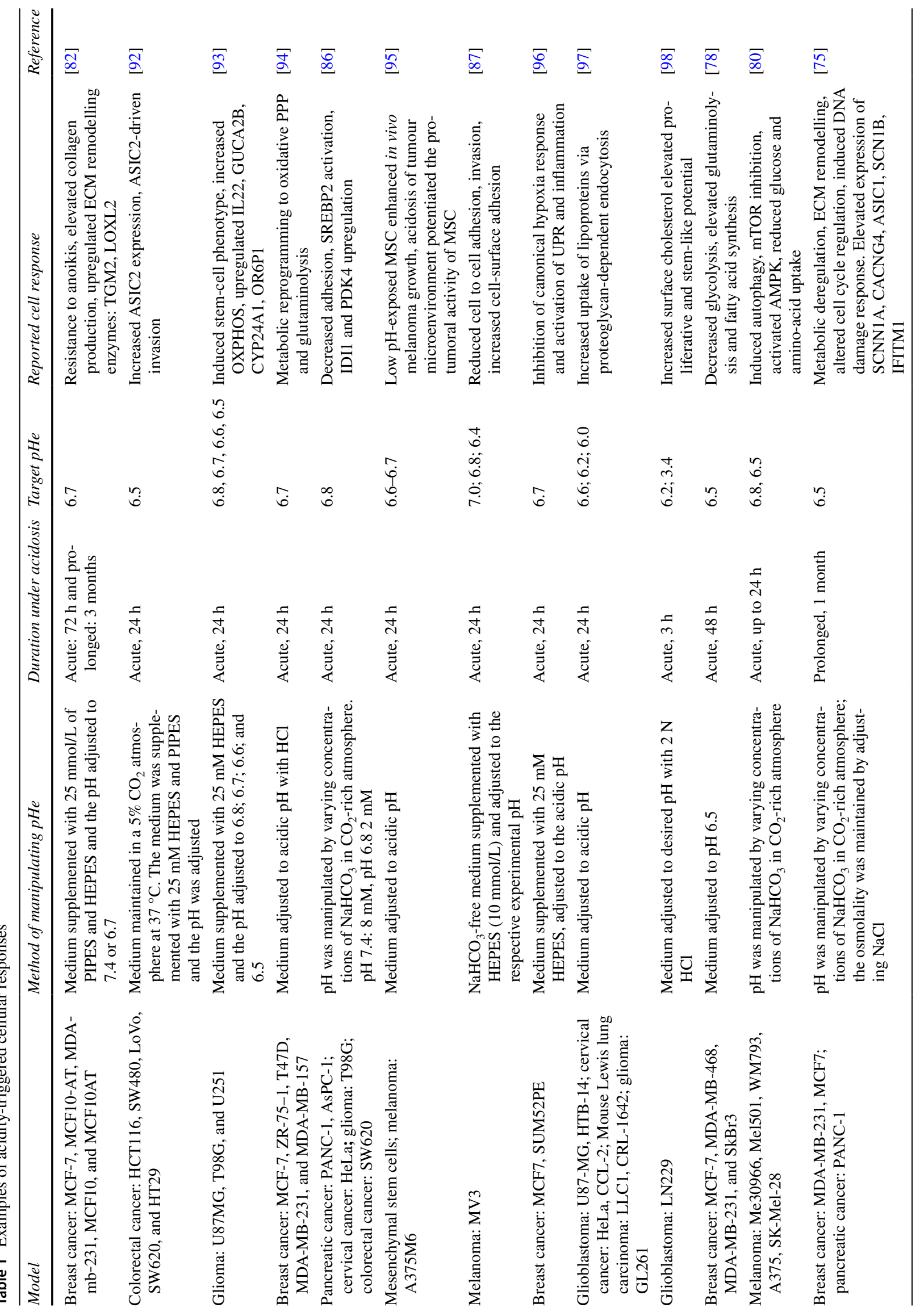




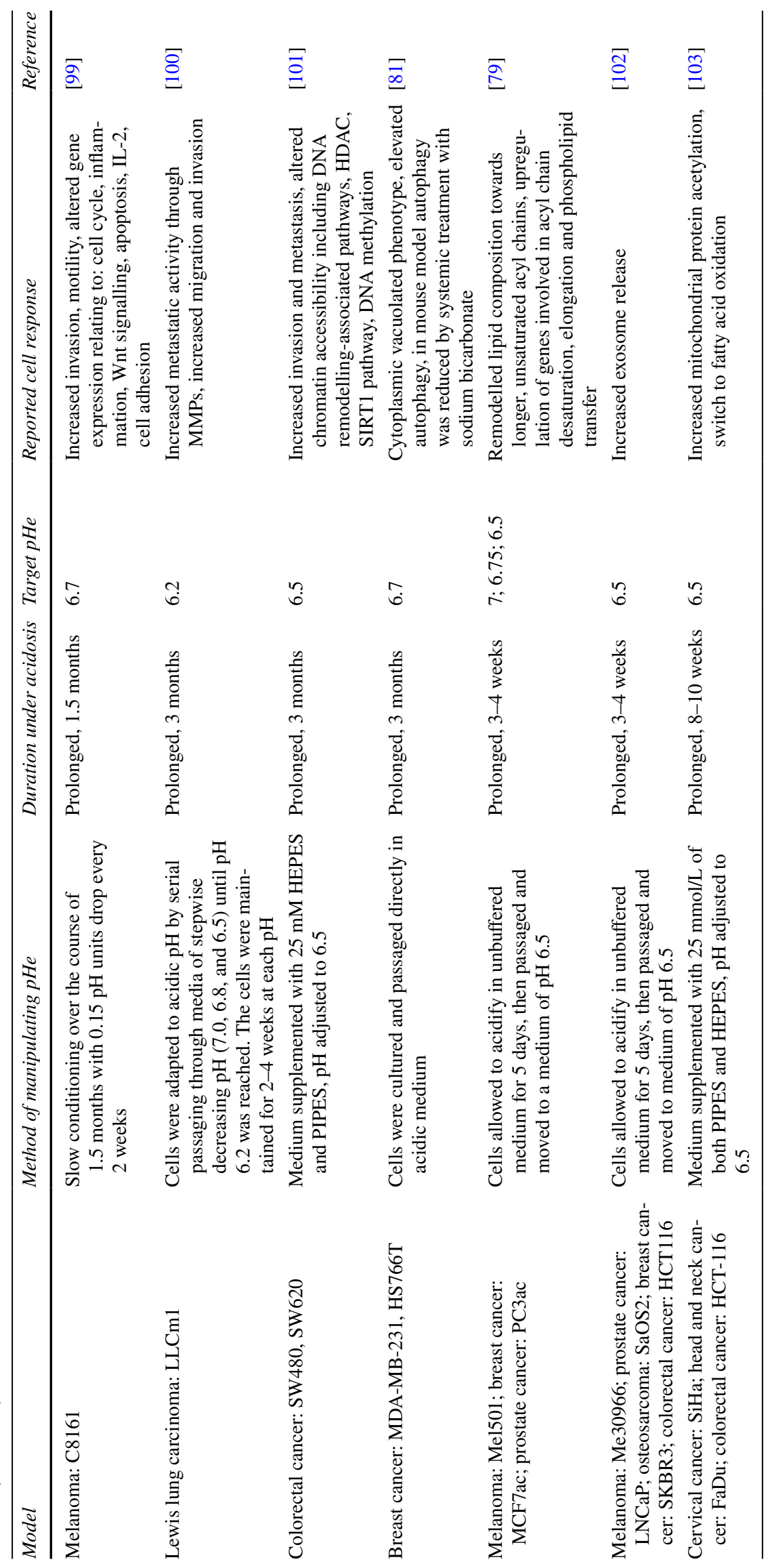


Table 2 Extracellular $\mathrm{pH}$ reported in tumours. Measurement methods are chemical exchange saturation transfer (CEST), magnetic resonance imaging (MRI), biosensor imaging of redundant deviation in shifts (BIRDS), paramagnetic chemical exchange saturation transfer (PARACEST), ${ }^{13} \mathrm{C}$-labelled zymonic acid (ZA), variable radio frequency proton-electron paramagnetic resonance (EPR), and $\mathrm{pH}$ microelectrode double-resonance imaging (VRF PEDRI), electron

\begin{tabular}{llll}
\hline Model & Method & $p H e$ & Reference \\
\hline Breast cancer (MMTV-Erbb2 transgenic mice) & CEST-MRI & $6.30-6.90$ & {$[109]$} \\
Hepatoma (McA-RH7777) & CEST-MRI & $\sim 6.80$ & {$[109]$} \\
Glioblastoma & BIRDS & $6.90 \pm 0.01$ & {$[110]$} \\
Bronchial tumours & pH-microelectrode & $6.46 \pm 0.35$ & {$[111]$} \\
Nonmetastatic breast cancer (TUBO) & CEST-MRI & $6.84 \pm 0.03$ & {$[114]$} \\
Triple negative breast cancer (4T1) & CEST-MRI & $6.79 \pm 0.02$ & {$[114]$} \\
Metastatic breast cancer (TS/A) & CEST-MRI & $6.80 \pm 0.03$ & {$[114]$} \\
Spontaneous lobular carcinoma (BALB-neuT) & CEST-MRI & $6.96 \pm 0.03$ & {$[114]$} \\
Hepatic carcinoma & CEST-MRI & $6.66 \pm 0.19$ & {$[115]$} \\
Hepatic hemangioma & CEST-MRI & $7.34 \pm 0.09$ & {$[115]$} \\
Glioma (U87) & CEST-MRI & $7.00 \pm 0.1$ & {$[116]$} \\
Glioma (U87) & CEST-MRI & $6.60 \pm 0.1$ & {$[116]$} \\
Breast cancer (MCF-7) & PARACEST-MRI & $\sim 6.50$ & {$[117]$} \\
MATB III adenocarcinoma & ZA-MRI & $6.82-7.11$ & {$[118]$} \\
Breast cancer (C57Bl/6 Met-1) & VRF PEDRI & $6.80 \pm 0.10$ & {$[119]$} \\
Pancreatic cancer (MIA-PaCa-2) & EPR & $\sim 7.05$ & {$[120]$} \\
Pancreatic cancer (SU.86.86) & EPR & $\sim 6.90$ & {$[120]$} \\
Pancreatic cancer (Hs766t) & EPR & $\sim 6.91$ & {$[120]$} \\
Prostate cancer (LNCap) & CEST-MRI & $6.78 \pm 0.29$ & {$[121]$} \\
Prostate cancer (PC-3) & CEST-MRI & $7.23 \pm 0.10$ & {$[121]$} \\
\hline
\end{tabular}

Fig. 4 Analysis of literature related to acidity and cancer. A Comparison between the extracellular $\mathrm{pH}$ reported within solid tumours (red) and $\mathrm{pHe}$ values selected for in vitro studies (blue). B Time under acidic conditions in studies using cultured cancer cell lines. The primary literature referred to these as long or short exposure, as indicated by empty and filled circles, respectively. References used in these analyses are listed in Tables 1 and 2

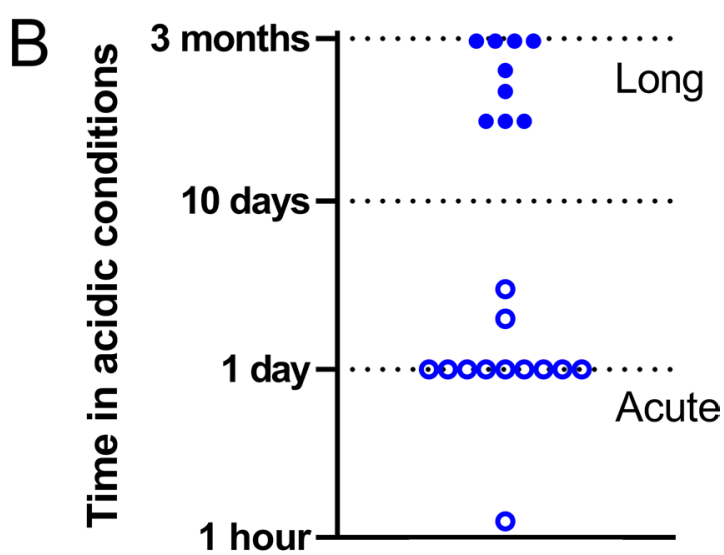

studies to undershoot the pHe range in tumours (Fig. 4A). To understand what level of $\mathrm{pHe}$ is appropriate for a cancer cell line, it is first important to recognise the factors responsible for setting the level of acidosis in a tumour and the degree to which this could be manipulated therapeutically.

pHe is ultimately set by the rate of metabolic acid production, working against the capacity to clear this with blood perfusion. These two processes are coupled together by the diffusion of $\mathrm{H}^{+}$ions across the extracellular compartment. In well-perfused tissues - where cell capillary distances are typically no more than a few microns - diffusive coupling is excellent. In this scenario, perfusion is expected to keep pHe close to 7.4 , even if the metabolic rate is very high (e.g. as is the case in the myocardium). The situation can be radically different in tumours that have abnormal vascular penetration. Here, diffusion distances can expand to hundreds of microns, generating $\mathrm{pHe}$ gradients across the extracellular space. The molecular pathways responsible for these expanded diffusional distances relate to the extent of vascular penetration and are typically guided by hypoxia and evoked by factors such as vascular endothelial growth factor (VEGF) [122-127]. These processes become deranged in tumours, leading to inadequate and often fluctuating perfusion [128-130] and can be manipulated with drugs such as anti-VEGF therapies [131-134], which may exert at least a part of their action via a change in pHe. In such 
diffusion-limited environments, $\mathrm{pHe}$ can be driven downwards by metabolism, particularly by glycolysis because lactic acid is a stronger acid of slower mobility compared to mitochondrially generated $\mathrm{CO}_{2}$. The balance between these fluxes can be altered by inhibitors. For example, blockers of oxidative phosphorylation force cells to rely more on glycolysis [135]. Conversely, inhibitors of glucose uptake can lessen glycolytic rate and hence lactic acid production [136], as would inhibitor of monocarboxylate transporters (MCT), the main route of lactic acid efflux from cells [137, 138]. The effective diffusion coefficients of these acidic products will depend on the equilibration state of $\mathrm{CO}_{2} / \mathrm{HCO}_{3}{ }^{-}$, as this depends on the activity of exofacial carbonic anhydrases (CAs), such as CAIX or CAXII [139-145]. As described previously [146], the effect of CA activity on pHe depends on the nature of the disturbance. Net release of $\mathrm{CO}_{2}$ drives equilibrium towards hydration and thus $\mathrm{CA}$ activity would support further acidification [139]; in contrast, the release of $\mathrm{H}^{+}$ions, such as in the form of lactic acid via monocarboxylate transporters (MCTs) would drive the reverse reaction, and CA catalysis would tend to raise pHe [146].

Metabolism will drive $\mathrm{pHe}$ to a lower level until it stabilises at a steady state. This scenario is reached when metabolic flux generated by cancer cells comes into balance with the diffusive flux across the poorly perfused tumour interstitium. As pHe falls, the diffusive gradient becomes steeper, which drives a larger diffusion flux of $\mathrm{H}^{+}$ions. Eventually, this diffusive flux will match metabolic output and result in a steady-state $\mathrm{pHe}$. The steady-state $\mathrm{pHe}$ could be attained at a less acidic level if metabolic rate became curtailed at low pHe; indeed, this is the case for glycolysis which is inhibited under acidic conditions [147]. Since glycolysis essentially ceases below pHe 6, tumour pHe is unlikely to fall below this level, as there is no obvious alternative source of acid that would drive $\mathrm{pHe}$ any lower. To summarise, tumour $\mathrm{pHe}$ depends on the rate of perfusion, diffusion distance, metabolic rate and its $\mathrm{pH}$-dependence. It is important to consider these variables in the context of a particular tumour before designing experiments on cell lines that probe responses to acidosis.

Once an appropriate target $\mathrm{pHe}$ is determined for a particular investigation, the next step is to consider how to attain this acid-base balance experimentally. Various strategies for reducing $\mathrm{pHe}$ have been used in previous studies, ranging from an abrupt drop to the target $\mathrm{pHe}$ [98], to a more graded change over an extended period of time [82] (Fig. 4B). An alternative approach is to allow cancer metabolism itself to gradually acidify the milieu until the target $\mathrm{pHe}$ is attained $[79,102]$. Although slow to reach its target, this method has the advantage that the source of acidity is endogenous and the final $\mathrm{pHe}$ is within the scope of the cell's capacity to acidify its milieu. These three distinct pHe manoeuvres may produce radically different responses, even if the same end point $\mathrm{pHe}$ is reached because various degrees of acid selection and acid adaptation may take place. The interpretation of experimental outcomes must carefully consider the nature of the acid-base intervention.

A treatment will result in selection if it is survived by a subpopulation of cells only. This scenario would be favoured by large and abrupt pHe changes [148], such as those arising from a single medium change [98]. Although acid selection has been discussed at length in theoretical models of cancer [149-156], it is poorly characterised experimentally. Part of the reason is that the surviving cellular subpopulations may be very sparse and therefore inadequate for certain types of measurements. In contrast, adaptation will take place when the $\mathrm{pHe}$ change is slower because it gives cells time to respond. A dominance of acid adaptation over acid selection is most likely when metabolism is responsible for acidification because negative feedback circuits acting on metabolic rate protect against unmanageably fast $\mathrm{pHe}$ changes. The interpretation of experimental results must carefully consider the time line over which $\mathrm{pHe}$ was changed and include this information in the methodological write-up. Many of the experimental descriptions of acid responses may, in fact, relate to a combination of early-onset acid selection, followed by acid adaptation in the surviving cells. Some insight into these processes can be obtained by running parallel experiments that differ in the rate of $\mathrm{pHe}$ change, relative to cell doubling time. This is a worthwhile exercise because the distinction between acid selection and acid adaptation has implications on the phenotypic landscape of a tumour, and hence susceptibility to therapies. In principle, it would be feasible to vary tumour pHe dynamically or even impose bespoke waveforms that alter the balance between selection and adaptation and influence the evolution of cancer populations.

\section{Exploiting acidosis in cancer therapies}

It is conceivable that some of the pro-oncogenic consequences of low $\mathrm{pHe}$ could be reversed by raising the $\mathrm{pHe}$ of solid tumours in vivo. This strategy is among the three predicted to have anticancer efficacy by evolution models (Fig. 2). The most thoroughly studied approach to increasing the $\mathrm{pH}$ within the tumour microenvironment is the systemic administration of bicarbonate. This so-called buffer therapy decreased metastasis formation [157], restored immune function [158], reduced tumour growth [159], and extended overall survival [160]. However, the issue with oral supplementation of bicarbonate in humans is the required dose, which is too high for comfortable administration thus severely limiting patient adherence [161]. To circumvent this compliance issue, a recent study replaced systemic administration with local delivery [162]; this significantly enhanced 
the efficacy of therapeutic transarterial chemoembolization, yielding $100 \%$ response in the combination-treated group. Some studies tested alternative buffering formulations, including Tris [163] and IEPA [164], but these are yet to be tested in a clinical setting. Another proposed way of raising $\mathrm{pHe}$ is the injection of urease, an enzyme that produces $\mathrm{NH}_{4}{ }^{+}$and $\mathrm{HCO}_{3}{ }^{-}$from urea, and thereby increases buffering locally. This intervention reduced tumour load and elevated the efficiency of chemotherapeutics in a mouse model of breast cancer [165].

An attractive therapeutic strategy that exploits $\mathrm{pH}$ combines the effect of $\mathrm{pH}$ changes on cancer cells and on immune surveillance. This approach targets two methods predicted to curtail cancer growth (Fig. 2). The effects of acidosis on immune function have been summarised by Damagaci et al. [166]. Briefly, extracellular acidity is deemed an immunosuppressor as it is associated with T-cell anergy [167]. The function of tumour-specific $\mathrm{CD} 8^{+} \mathrm{T}$ lymphocytes is impaired under acidic conditions, which manifests in decreased cytokine secretion and cytolytic activity [168]. Intriguingly, acidic niches in lymph nodes have a physiological role in suppressing resident T cells [169], and this mechanism is believed to be hijacked by solid tumours. Recent results confirmed the negative effects of acidosis on dendritic cells in terms of reduced migration, membrane, and cytoskeletal properties [170]. Similarly, high extracellular lactate concentrations, as an inseparable component to lactic acidosis, reduce migration and cytotoxicity of $\mathrm{CD} 4^{+}$ and $\mathrm{CD} 8^{+}$lymphocytes [171]. Moreover, both lactate and $\mathrm{H}^{+}$ions limit the function of macrophages by suppressing inflammasome formation [172] and promoting macrophage polarization [173]. It was reported that prolonged lactic acidosis leads to monocyte differentiation into proinflammatory macrophages of pro-tumour phenotype [174]. A detailed description of the interplay between lactate and immunity was recently reviewed by Caslin et al. [171].

\section{Evolution, fitness, and heterogeneity}

The discussion thus far has been limited to a notional population of 'cancer' and 'normal' cells forming a binary society in a tissue. However, an inalienable feature of cancer is its ability to evolve and pass on favourable characteristics to daughter cells, without being subject to the checks and controls that constrain normal cells. This process resembles the evolution of species in ecosystems, and its applicability to cancer was recognised by Peter Nowell in the 1970s [175]. The mathematical framework used to understand evolution is called game theory because a cell (player) takes on a strategy (phenotype) tailored to the strategies of other cells (co-players), with the aim to increase occupancy in the host tissues (assets) [176]. Evolution can be quantified in terms of phenotypic change over time [177]. This process can be described mathematically as the product of two components:

- The slope of the fitness/phenotype curve. This describes how the cell's ability to survive a particular scenario is altered by a change in its phenotype. Changes to a phenotype that do not affect cell fitness will not drive evolution. In contrast, fitness that is conferred only by a narrow range of phenotypes will drive rapid evolution (Fig. 5A).

- The degree of variation in phenotype within the population of cells. Populations that show no heterogeneity will evolve slowly, whereas those with substantial diversity provide the substrate for evolution (Fig. 5B).

A faster pace of evolution is expected for populations that manifest broader phenotypic variation and for which even a small change in phenotype can meaningfully impact fitness to survive. Cancers that manifest these properties are more challenging to control therapeutically because a constant drug regime will eventually enrich the tumour in resistant cells. This situation is likely in tumours of high histological grading, wherein undifferentiated cells with stem-like properties have unlimited options to differentiate in response to selection pressures [178-181]. Despite the elegant simplicity of the equation governing the rate of phenotypic change, concepts such as 'fitness sensitivity' or 'phenotypic heterogeneity' are difficult to articulate in biological terms and interrogate experimentally. In the specific context of acidosis, many questions remain about the relationship between $\mathrm{pHe}$, phenotype, fitness, and heterogeneity.

Phenotype The emphasis on phenotype, rather than genotype, in somatic evolution is justified because selection favours particular functional outcomes, rather than their genetic instruction [177]. In the context of cancer cells, phenotype could refer to ensemble measures such as the proliferative rate or more elementary features such as glycolytic rate. For most normal cells in the body, it would be appropriate to quantify these phenotypes at pHe 7.4, i.e. the interstitial $\mathrm{pHe}$ of most tissues. The situation becomes more complicated in tumours, where $\mathrm{pHe}$ can be displaced from 7.4 and meaningfully influence phenotype. This raises the question of whether pHe sensitivity should be included in the definition of cancer phenotypes. Although $\mathrm{pHe}$ is ultimately influenced by the tissue's genetic blueprint for metabolic acid production, extracellular buffering and volume, and blood perfusion, it is not normally considered an inheritable property in the same way that enzyme activity would be. Notwithstanding these questions, it is inevitable that mathematical representations of cancer will become 
A
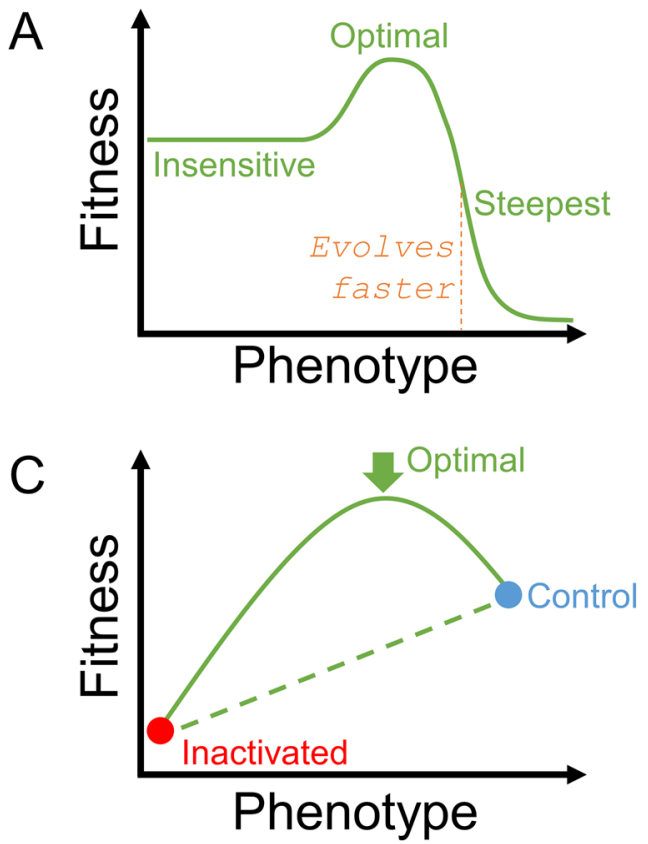

B
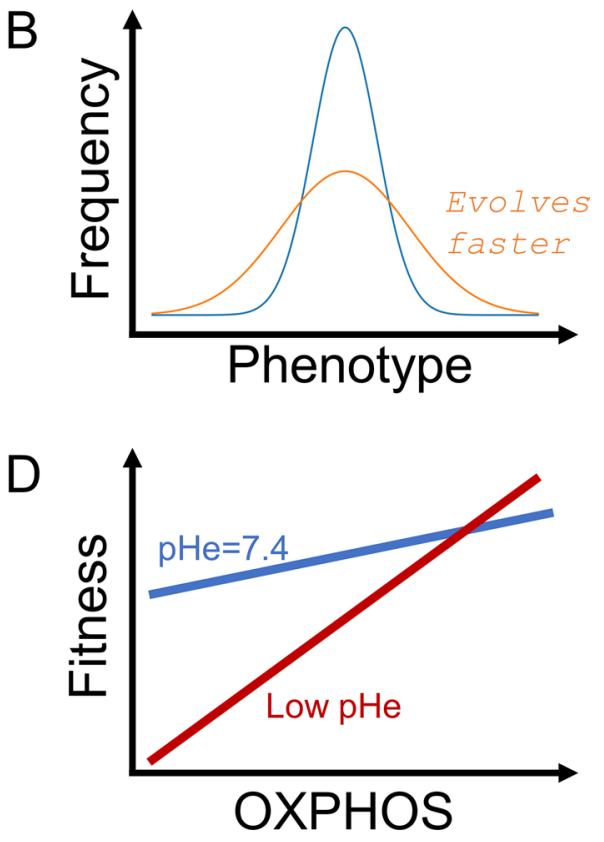

Fig. 5 Understanding somatic evolution in terms of fitness and phenotypic heterogeneity. A Example of a fitness-phenotype relationship, showing a highly nonlinear behaviour. Optimal fitness is associated with an intermediate phenotype. The fastest rate of evolution is predicted around phenotypes that produce the steepest change in fitness. B Wider phenotypic variation is associated with higher rates of evolution. C Experiments that compare a control phenotype with a pharmacologically or genetically inactivated phenotype may miss impor-

more comprehensive and mechanistic and eventually include pHe sensitivity.

Fitness The canonical approach to exploring the relationship between cellular fitness and phenotype has been pharmacological (e.g. inhibitors to block a specific process) or genetic (e.g. using overexpression or ablation to manipulate gene expression). In most studies, these investigations have been binary, e.g. comparing control with the inactivated state. While this approach has made way for some major discoveries, it actually contributes little to our understanding of somatic evolution. This is because the phenotype is a continuous variable, and its effect on cellular fitness can be highly nonlinear. As a result, probing fitness at only two phenotypic states sheds little light on fitness over the whole range of possible phenotypes. For example, the relationship between fitness and phenotype may produce optimal survival at an intermediate phenotype that would go undetected with the canonical pharmacological or genetic approach (Fig. 5C). Thus, measurements of fitness in the context of evolution must take into account that phenotype is a continuous variable and use appropriate methods to explore phenotypic responses with the necessary granularity. One method for smoothly grading phenotype exploits pHe sensitivity. tant information about fitness. In this example, optimal fitness was attained at an intermediate phenotype and would not be detected with the canonical experimental approach. D The relationship between a phenotype and fitness can change in response to constraints placed by the environment. In this example, low pHe inhibits glycolysis, which forces the cell to rely more on oxidative phosphorylation (OXPHOS); this manifests as a steeper fitness-OXPHOS curve and therefore a higher rate of evolution

Cancers may use pHe to fine-tune phenotype to a level that maximises the rate of evolution. pHe may also change the shape of the fitness-phenotype relationship by imposing constraints on cells. For example, low pHe inhibits glycolysis, which forces cells to rely more on oxidative phosphorylation. In such circumstances, cellular fitness becomes steeply dependent on mitochondrial metabolism, as compared to the alternative scenario at physiological pHe (Fig. 5D).

Heterogeneity Phenotypic heterogeneity is possibly the least understood aspect of cancer cells. While it is tempting to use genotypic heterogeneity as a surrogate for phenotypic heterogeneity, the nontrivial coupling between genes and function largely invalidates this shortcut [182]. The conventional experimental approach of measuring phenotype has been to report its mean and standard error. This reporting convention focuses on conveying the average state of the population but fails to describe variation. Single-cell technologies, which have revolutionised transcriptomics [183-186], must now be extended for phenotyping. In reality, few phenotypes can be recorded at the necessary singlecell resolution. Moreover, a compounding issue is how to deconvolute experimental noise from genuine biological variance $[187,188]$. Certain methods that have had a role in 
physiology research are compatible with single-cell measurements (e.g. cell fluorescence-based assays [189-191]) and an ambitious upscaling of these techniques can provide the information required to describe heterogeneity at the population level.

\section{Summary}

The effects of acidity on cancer cells have often been described in terms of ill-defined cytotoxicity, akin to the actions of a 'dirty' yet potent drug. However, the role of acidity in tumours is much more nuanced than that of a cytotoxic drug. Firstly, acidity is an intrinsic feature of the tumour that is present throughout much of the process of carcinogenesis, albeit at varying degrees of intensity. Thus, acidity can exercise a persistent effect on cancer cells, which could be exploited therapeutically to produce a sustained shift in the tumour's phenotypic landscape away from the most invasive type. This is in contrast to cytotoxic drugs that may exert a selection pressure during treatment episodes, but this effect cannot be sustained in the long term and may result in cancer recurrence, as predicted by mathematical models. Secondly, $\mathrm{pH}$ can influence the interaction between cancer cells and their host tissue, which has been highlighted by mathematical models as a viable treatment strategy. For example, low pHe targets host defences by suppressing immune surveillance. Releasing this inhibitory effect could empower the host tissue to eliminate cancer cells. Thirdly, $\mathrm{pH}$ is a fundamental property of the chemical microenvironment that is directly influenced by cells and feeds back on their survival prospects. Under acid stress, the selection of a fitter cancer subpopulation or adaptation towards a more compatible phenotype can endow cancer cells with a competitive advantage over host cells. Attenuating these pHe-driven processes could steer the cancer/host system away from the invasive trajectory. In this review, we have highlighted areas related to the acidosis that require further research attention, namely the heterogeneity of $\mathrm{pH}$-related phenotypes, the aspects of fitness that are most sensitive to $\mathrm{pH}$, and how best to achieve control over $\mathrm{pHe}$ in vivo. We have also explained the importance of adequate reporting standards and how to translate mathematical concepts borne from models into biological terms that could be tested experimentally.

\section{Declarations}

Competing interests The authors declare no competing interests.

Open Access This article is licensed under a Creative Commons Attribution 4.0 International License, which permits use, sharing, adaptation, distribution and reproduction in any medium or format, as long as you give appropriate credit to the original author(s) and the source, provide a link to the Creative Commons licence, and indicate if changes were made. The images or other third party material in this article are included in the article's Creative Commons licence, unless indicated otherwise in a credit line to the material. If material is not included in the article's Creative Commons licence and your intended use is not permitted by statutory regulation or exceeds the permitted use, you will need to obtain permission directly from the copyright holder. To view a copy of this licence, visit http://creativecommons. org/licenses/by/4.0/.

\section{References}

1. WHO (2021). Cancer. https://www.who.int/news-room/factsheets/detail/cancer. Accessed 15.09.2021.

2. NCI (2020). Cancer Statistics. https://www.cancer.gov/aboutcancer/understanding/statistics.

3. Chen, B., Sirota, M., Fan-Minogue, H., Hadley, D., \& Butte, A. J. (2015). Relating hepatocellular carcinoma tumor samples and cell lines using gene expression data in translational research. BMC Medical Genomics, 8(Suppl 2), S5. https://doi.org/10.1186/ 1755-8794-8-S2-S5

4. Domcke, S., Sinha, R., Levine, D. A., Sander, C., \& Schultz, N. (2013). Evaluating cell lines as tumour models by comparison of genomic profiles. Nature Communications, 4, ARTN2126. https://doi.org/10.1038/ncomms3126

5. Jiang, G., Zhang, S., Yazdanparast, A., Li, M., Pawar, A. V., Liu, Y., et al. (2016). Comprehensive comparison of molecular portraits between cell lines and tumors in breast cancer. BMC Genomics, 17(Suppl 7), 525. https://doi.org/10.1186/ s12864-016-2911-z

6. Ye, F., Chen, C., Qin, J., Liu, J., \& Zheng, C. (2015). Genetic profiling reveals an alarming rate of cross-contamination among human cell lines used in China. The FASEB Journal, 29(10), 4268-4272. https://doi.org/10.1096/fj.14-266718

7. Wilding, J. L., \& Bodmer, W. F. (2014). Cancer cell lines for drug discovery and development. Cancer Research, 74(9), 2377-2384. https://doi.org/10.1158/0008-5472.CAN-13-2971

8. Baker, M. (2016). 1,500 scientists lift the lid on reproducibility. Nature, 533(7604), 452-454. https://doi.org/10.1038/533452a

9. Begley, C. G., \& Ellis, L. M. (2012). Drug development: Raise standards for preclinical cancer research. Nature, 483(7391), 531-533. https://doi.org/10.1038/483531a

10. Hutchinson, L., \& Kirk, R. (2011). High drug attrition ratesWhere are we going wrong? Nature Reviews. Clinical Oncology, 8(4), 189-190. https://doi.org/10.1038/nrclinonc.2011.34

11. Stratton, M. R., Campbell, P. J., \& Futreal, P. A. (2009). The cancer genome. Nature, 458(7239), 719-724. https://doi.org/10. 1038/nature07943

12. Gillet, J. P., Varma, S., \& Gottesman, M. M. (2013). The clinical relevance of cancer cell lines. Journal of the National Cancer Institute, 105(7), 452-458. https://doi.org/10.1093/jnci/djt007

13. Mirabelli, P., Coppola, L., \& Salvatore, M. (2019). Cancer cell lines are useful model systems for medical research. Cancers (Basel), 11(8), https://doi.org/10.3390/cancers11081098.

14. Capes-Davis, A., Bairoch, A., Barrett, T., Burnett, E. C., Dirks, W. G., Hall, E. M., et al. (2019). Cell lines as biological models: Practical steps for more reliable research. Chemical Research in Toxicology, 32(9), 1733-1736. https://doi.org/10.1021/acs.chemr estox.9b00215

15. MacLeod, R. A., Dirks, W. G., Matsuo, Y., Kaufmann, M., Milch, H., \& Drexler, H. G. (1999). Widespread intraspecies cross-contamination of human tumor cell lines arising at source. 
International Journal of Cancer, 83(4), 555-563. https://doi.org/ 10.1002/(sici)1097-0215(19991112)83:4\%3c555::aid-ijc19\% 3e3.0.co;2-2

16. Ackermann, T., \& Tardito, S. (2019). Cell culture medium formulation and its implications in cancer metabolism. Trends Cancer, 5(6), 329-332. https://doi.org/10.1016/j.trecan.2019.05.004

17. Vande Voorde, J., Ackermann, T., Pfetzer, N., Sumpton, D., Mackay, G., Kalna, G., et al. (2019). Improving the metabolic fidelity of cancer models with a physiological cell culture medium. Science Advances, 5(1), eaau7314. https://doi.org/10.1126/sciadv. aau7314

18. Vis, M. A. M., Ito, K., \& Hofmann, S. (2020). Impact of culture medium on cellular interactions in in vitro co-culture systems. Front Bioeng Biotechnol, 8, 911. https://doi.org/10.3389/fbioe. 2020.00911

19. Curtis, K. J., Schiavi, J., Mc Garrigle, M. J., Kumar, V., McNamara, L. M., \& Niebur, G. L. (2020). Mechanical stimuli and matrix properties modulate cancer spheroid growth in threedimensional gelatin culture. Journal of the Royal Society, Interface, 17(173), 20200568. https://doi.org/10.1098/rsif.2020.0568

20. Dong, Y., Zheng, Q., Wang, Z., Lin, X., You, Y., Wu, S., et al. (2019). Higher matrix stiffness as an independent initiator triggers epithelial-mesenchymal transition and facilitates HCC metastasis. Journal of Hematology \& Oncology, 12(1), 112. https://doi.org/10.1186/s13045-019-0795-5

21. Park, J. S., Burckhardt, C. J., Lazcano, R., Solis, L. M., Isogai, T., Li, L., et al. (2020). Mechanical regulation of glycolysis via cytoskeleton architecture. Nature, 578(7796), 621-626. https:// doi.org/10.1038/s41586-020-1998-1

22. Capes-Davis, A., Theodosopoulos, G., Atkin, I., Drexler, H. G., Kohara, A., MacLeod, R. A., et al. (2010). Check your cultures! A list of cross-contaminated or misidentified cell lines. International Journal of Cancer, 127(1), 1-8. https://doi.org/10.1002/ ijc. 25242

23. Nelson-Rees, W. A., Daniels, D. W., \& Flandermeyer, R. R. (1981). Cross-contamination of cells in culture. Science, 212(4493), 446-452. https://doi.org/10.1126/science.6451928

24. Hanahan, D., \& Weinberg, R. A. (2000). The hallmarks of cancer. Cell, 100(1), 57-70. https://doi.org/10.1016/s0092-8674(00) 81683-9

25. Hanahan, D., \& Weinberg, R. A. (2011). Hallmarks of cancer: The next generation. Cell, 144(5), 646-674. https://doi.org/10. 1016/j.cell.2011.02.013

26. Miescher, S., Whiteside, T. L., Moretta, L., \& von Fliedner, V. (1987). Clonal and frequency analyses of tumor-infiltrating T lymphocytes from human solid tumors. The Journal of Immunology, 138(11), 4004-4011.

27. Vaupel, P., Kallinowski, F., \& Okunieff, P. (1989). Blood flow, oxygen and nutrient supply, and metabolic microenvironment of human tumors: A review. Cancer Research, 49(23), 6449-6465.

28. Vaupel, P., Kallinowski, F., \& Okunieff, P. (1990). Blood flow, oxygen consumption and tissue oxygenation of human tumors. Advances in Experimental Medicine and Biology, 277, 895-905.

29. Verloes, R., \& Kanarek, L. (1976). Tumour microenvironment studies open new perspectives for immunotherapy. Archives Internationales de Physiologie et de Biochimie, 84(2), 420-422.

30. Mueller-Klieser, W., Vaupel, P., \& Manz, R. (1983). Tumour oxygenation under normobaric and hyperbaric conditions. British Journal of Radiology, 56(668), 559-564. https://doi.org/10.1259/ 0007-1285-56-668-559

31. Brown, J. M. (1979). Evidence for acutely hypoxic cells in mouse-tumors, and a possible mechanism of re-oxygenation. British Journal of Radiology, 52(620), 650-656. https://doi.org/ 10.1259/0007-1285-52-620-650

32. van den Berg, A. P., Wike-Hooley, J. L., Broekmeyer-Reurink, M. P., van der Zee, J., \& Reinhold, H. S. (1989). The relationship between the unmodified initial tissue $\mathrm{pH}$ of human tumours and the response to combined radiotherapy and local hyperthermia treatment. European Journal of Cancer \& Clinical Oncology, 25(1), 73-78. https://doi.org/10.1016/0277-5379(89)90053-9

33. van den Berg, A. P., Wike-Hooley, J. L., van den Berg-Blok, A. E., van der Zee, J., \& Reinhold, H. S. (1982). Tumour $\mathrm{pH}$ in human mammary carcinoma. European Journal of Cancer \& Clinical Oncology, 18(5), 457-462. https://doi.org/10.1016/ 0277-5379(82)90114-6

34. Wike-Hooley, J. L., Haveman, J., \& Reinhold, H. S. (1984). The relevance of tumour $\mathrm{pH}$ to the treatment of malignant disease. Radiotherapy and Oncology, 2(4), 343-366.

35. Wike-Hooley, J. L., Van der Zee, J., van Rhoon, G. C., Van den Berg, A. P., \& Reinhold, H. S. (1984). Human tumour pH changes following hyperthermia and radiation therapy. European Journal of Cancer \& Clinical Oncology, 20(5), 619-623. https:// doi.org/10.1016/0277-5379(84)90006-3

36. Warburg, O., Wind, F., \& Negelein, E. (1927). The metabolism of tumors in the body. Journal of General Physiology, 8(6), 519-530. https://doi.org/10.1085/jgp.8.6.519

37. Kostakoglu, L., Agress, H., Jr., \& Goldsmith, S. J. (2003). Clinical role of FDG PET in evaluation of cancer patients. Radiographics, 23(2), 315-340; quiz 533, https://doi.org/10.1148/rg. 232025705.

38. Zhu, A., Lee, D., \& Shim, H. (2011). Metabolic positron emission tomography imaging in cancer detection and therapy response. Seminars in Oncology, 38(1), 55-69. https://doi.org/ 10.1053/j.seminoncol.2010.11.012

39. Walenta, S., Wetterling, M., Lehrke, M., Schwickert, G., Sundfor, K., Rofstad, E. K., et al. (2000). High lactate levels predict likelihood of metastases, tumor recurrence, and restricted patient survival in human cervical cancers. Cancer Research, 60(4), 916-921.

40. Nwosu, Z. C., Battello, N., Rothley, M., Pioronska, W., Sitek, B., Ebert, M. P., et al. (2018). Liver cancer cell lines distinctly mimic the metabolic gene expression pattern of the corresponding human tumours. Journal of Experimental \& Clinical Cancer Research, 37, ARTN 211. https://doi.org/10.1186/ s13046-018-0872-6

41. Russell, S., Wojtkowiak, J., Neilson, A., \& Gillies, R. J. (2017). Metabolic profiling of healthy and cancerous tissues in 2D and 3D. Scientific Reports, 7, ARTN 15285. https://doi.org/10.1038/ s41598-017-15325-5

42. Horsman, M. R., Khalil, A. A., Siemann, D. W., Grau, C., Hill, S. A., Lynch, E. M., et al. (1994). Relationship between radiobiological hypoxia in tumors and electrode measurements of tumor oxygenation. International Journal of Radiation Oncology Biology Physics, 29(3), 439-442. https://doi.org/10.1016/ 0360-3016(94)90434-0

43. Rofstad, E. K., Lyng, H., Olsen, D. R., \& Steinsland, E. (1994). Non-invasive assessment of tumor oxygenation status by integrated 31P NMR spectroscopy and 1H NMR imaging. Advances in Experimental Medicine and Biology, 345, 531-538. https:// doi.org/10.1007/978-1-4615-2468-7_71

44. Zeltzer, P. M., Friedman, H. S., Norris, D. G., \& Ragab, A. H. (1985). Criteria and definitions for response and relapse in children with brain tumors. Cancer, 56(7 Suppl), 1824-1826. https://doi.org/10.1002/1097-0142(19851001)56:7+\%3c1824:: aid-cncr2820561321\%3e3.0.co;2-h

45. Walker, M. D., Alexander, E., Jr., Hunt, W. E., Leventhal, C. M., Mahaley, M. S., Jr., Mealey, J., et al. (1976). Evaluation of mithramycin in the treatment of anaplastic gliomas. Journal of Neurosurgery, 44(6), 655-667. https://doi.org/10.3171/jns.1976. 44.6.0655

46. Michl, J., Park, K. C., \& Swietach, P. (2019). Evidence-based guidelines for controlling $\mathrm{pH}$ in mammalian live-cell culture 
systems. Communications Biology, 2, 144. https://doi.org/10. 1038/s42003-019-0393-7

47. Geraghty, R. J., Capes-Davis, A., Davis, J. M., Downward, J., Freshney, R. I., Knezevic, I., et al. (2014). Guidelines for the use of cell lines in biomedical research. British Journal of Cancer, 111(6), 1021-1046. https://doi.org/10.1038/bjc.2014.166

48. Rizner, T. L., \& Adamski, J. (2018). It is high time to discontinue use of misidentified and contaminated cells: Guidelines for description and authentication of cell lines. Journal of Steroid Biochemistry and Molecular Biology, 182, 1-3. https://doi.org/ 10.1016/j.jsbmb.2017.12.017

49. Enriquez-Navas, P. M., Wojtkowiak, J. W., \& Gatenby, R. A. (2015). Application of evolutionary principles to cancer therapy. Cancer Research, 75(22), 4675-4680. https://doi.org/10.1158/ 0008-5472.CAN-15-1337

50. Gatenby, R. A., \& Brown, J. S. (2020). Integrating evolutionary dynamics into cancer therapy. Nature Reviews. Clinical Oncology, 17(11), 675-686. https://doi.org/10.1038/ s41571-020-0411-1

51. Gatenby, R. A., Gillies, R. J., \& Brown, J. S. (2010). Evolutionary dynamics of cancer prevention. Nature Reviews Cancer, 10(8), 526-527. https://doi.org/10.1038/nrc2892

52. Park, D. S., Luddy, K. A., Robertson-Tessi, M., O'Farrelly, C., Gatenby, R. A., \& Anderson, A. R. A. (2020). Searching for Goldilocks: How evolution and ecology can help uncover more effective patient-specific chemotherapies. Cancer Research, 80(23), 5147-5154. https://doi.org/10.1158/0008-5472. CAN-19-3981

53. Gatenby, R. A., \& Vincent, T. L. (2003). Application of quantitative models from population biology and evolutionary game theory to tumor therapeutic strategies. Molecular Cancer Therapeutics, 2(9), 919-927.

54. Kanno, A., Masamune, A., Hanada, K., Maguchi, H., Shimizu, Y., Ueki, T., et al. (2018). Multicenter study of early pancreatic cancer in Japan. Pancreatology, 18(1), 61-67. https://doi.org/ 10.1016/j.pan.2017.11.007

55. Hahnfeldt, P., Panigrahy, D., Folkman, J., \& Hlatky, L. (1999). Tumor development under angiogenic signaling: A dynamical theory of tumor growth, treatment response, and postvascular dormancy. Cancer Research, 59(19), 4770-4775.

56. Gatenby, R. A., \& Maini, P. K. (2003). Mathematical oncology: Cancer summed up. Nature, 421(6921), 321. https://doi.org/10. $1038 / 421321 \mathrm{a}$

57. Kozlowska, E., Suwinski, R., Giglok, M., Swierniak, A., \& Kimmel, M. (2020). Mathematical model predicts response to chemotherapy in advanced non-resectable non-small cell lung cancer patients treated with platinum-based doublet. Plos Computational Biology, 16(10), ARTN e1008234. https://doi. org/10.1371/journal.pcbi.1008234

58. Yousef, A., Bozkurt, F., \& Abdeljawad, T. (2020). Mathematical modeling of the immune-chemotherapeutic treatment of breast cancer under some control parameters. Advances in Difference Equations, 2020(1), ARTN 696. https://doi.org/10. 1186/s13662-020-03151-5

59. Unni, P., \& Seshaiyer, P. (2019). Mathematical modeling, analysis, and simulation of tumor dynamics with drug interventions. Computational and Mathematical Methods in Medicine, 2019, Artn 4079298. https://doi.org/10.1155/2019/4079298

60. Yang, L. V. (2017). Tumor microenvironment and metabolism. Int J Mol Sci, 18(12), https://doi.org/10.3390/ijms18122729.

61. Thomlinson, R. H., \& Gray, L. H. (1955). The histological structure of some human lung cancers and the possible implications for radiotherapy. British Journal of Cancer, 9(4), 539549. https://doi.org/10.1038/bjc.1955.55

62. Warburg, O. (1930). The metabolism of tumours. Arnold Constable.
63. Martin, N. K., Robey, I. F., Gaffney, E. A., Gillies, R. J., Gatenby, R. A., \& Maini, P. K. (2012). Predicting the safety and efficacy of buffer therapy to raise tumour pHe: An integrative modelling study. British Journal of Cancer, 106(7), 1280-1287. https://doi.org/10.1038/bjc.2012.58

64. Fellenz, M. P., \& Gerweck, L. E. (1988). Influence of extracellular $\mathrm{pH}$ on intracellular $\mathrm{pH}$ and cell energy status: Relationship to hyperthermic sensitivity. Radiation Research, 116(2), 305-312.

65. Wilson, W. R., \& Hay, M. P. (2011). Targeting hypoxia in cancer therapy. Nature Reviews Cancer, 11(6), 393-410. https://doi.org/ $10.1038 / \mathrm{nrc} 3064$

66. Eagle, H. (1971). Buffer combinations for mammalian cell culture. Science, 174(4008), 500-503. https://doi.org/10.1126/scien ce.174.4008.500

67. Ceccarini, C., \& Eagle, H. (1971). pH as a determinant of cellular growth and contact inhibition. Proceedings of the National Academy of Sciences of U S A, 68(1), 229-233. https://doi.org/ 10.1073/pnas.68.1.229

68. Ribeiro, M. D., Silva, A. S., Bailey, K. M., Kumar, N. B., Sellers, T. A., Gatenby, R. A., et al. (2012). Buffer Therapy for Cancer Journal of Nutrition \& Food Sciences, 2, 6.

69. Boedtkjer, E., \& Pedersen, S. F. (2020). The acidic tumor microenvironment as a driver of cancer. Annual Review of Physiology, 82, 103-126. https://doi.org/10.1146/annurev-physi ol-021119-034627

70. Ibrahim-Hashim, A., \& Estrella, V. (2019). Acidosis and cancer: From mechanism to neutralization. Cancer and Metastasis Reviews, 38(1-2), 149-155. https://doi.org/10.1007/ s10555-019-09787-4

71. Peppicelli, S., Bianchini, F., \& Calorini, L. (2014). Extracellular acidity, a "reappreciated" trait of tumor environment driving malignancy: Perspectives in diagnosis and therapy. Cancer and Metastasis Reviews, 33(2-3), 823-832. https://doi.org/10.1007/ s10555-014-9506-4

72. Damaghi, M., Wojtkowiak, J. W., \& Gillies, R. J. (2013). pH sensing and regulation in cancer. Frontiers in Physiology, 4, ARTN 370. https://doi.org/10.3389/fphys.2013.00370

73. Schonichen, A., Webb, B. A., Jacobson, M. P., \& Barber, D. L. (2013). Considering protonation as a posttranslational modification regulating protein structure and function. Annual Review of Biophysics, 42, 289-314. https://doi.org/10.1146/annurev-bioph ys-050511-102349

74. Ludwig, M. G., Vanek, M., Guerini, D., Gasser, J. A., Jones, C. E., Junker, U., et al. (2003). Proton-sensing G-protein-coupled receptors. Nature, 425(6953), 93-98. https://doi.org/10.1038/ nature01905

75. Yao, J., Czaplinska, D., Ialchina, R., Schnipper, J., Liu, B., Sandelin, A., et al. (2020). Cancer cell acid adaptation gene expression response is correlated to tumor-specific tissue expression profiles and patient survival. Cancers (Basel), 12(8), https://doi. org/10.3390/cancers12082183.

76. Sadeghi, M., Ordway, B., Rafiei, I., Borad, P., Fang, B., Koomen, J. L., et al. (2020). Integrative analysis of breast cancer cells reveals an epithelial-mesenchymal transition role in adaptation to acidic microenvironment. Frontiers in Oncology, 10, ARTN 304. https://doi.org/10.3389/fonc.2020.00304

77. Damaghi, M., Tafreshi, N. K., Lloyd, M. C., Sprung, R., Estrella, V., Wojtkowiak, J. W., et al. (2015). Chronic acidosis in the tumour microenvironment selects for overexpression of LAMP2 in the plasma membrane. Nature Communications, 6 , 8752. https://doi.org/10.1038/ncomms9752

78. Gao, J., Guo, Z., Cheng, J., Sun, B., Yang, J., Li, H., et al. (2020). Differential metabolic responses in breast cancer cell lines to acidosis and lactic acidosis revealed by stable isotope assisted 
metabolomics. Science and Reports, 10(1), 21967. https://doi. org/10.1038/s41598-020-78955-2

79. Urbanelli, L., Buratta, S., Logozzi, M., Mitro, N., Sagini, K., Raimo, R. D., et al. (2020). Lipidomic analysis of cancer cells cultivated at acidic $\mathrm{pH}$ reveals phospholipid fatty acids remodelling associated with transcriptional reprogramming. Journal of Enzyme Inhibition and Medicinal Chemistry, 35(1), 963-973. https://doi.org/10.1080/14756366.2020.1748025

80. Marino, M. L., Pellegrini, P., Di Lernia, G., Djavaheri-Mergny, M., Brnjic, S., Zhang, X., et al. (2012). Autophagy is a protective mechanism for human melanoma cells under acidic stress. Journal of Biological Chemistry, 287(36), 30664-30676. https:// doi.org/10.1074/jbc.M112.339127

81. Wojtkowiak, J. W., Rothberg, J. M., Kumar, V., Schramm, K. J., Haller, E., Proemsey, J. B., et al. (2012). Chronic autophagy is a cellular adaptation to tumor acidic $\mathrm{pH}$ microenvironments. Cancer Research, 72(16), 3938-3947. https://doi.org/10.1158/ 0008-5472.CAN-11-3881

82. Damaghi, M., Mori, H., Byrne, S., Xu, L., Chen, T., Johnson, J., et al. (2020). Collagen production and niche engineering: A novel strategy for cancer cells to survive acidosis in DCIS and evolve. Evolutionary Applications, 13(10), 2689-2703. https://doi.org/ 10.1111/eva.13075

83. Sadeghi, M., Ordway, B., Rafiei, I., Borad, P., Fang, B., Koomen, J. L., et al. (2020). Integrative analysis of breast cancer cells reveals an epithelial-mesenchymal transition role in adaptation to acidic microenvironment. Frontiers in Oncology, 10, 304. https:// doi.org/10.3389/fonc. 2020.00304

84. Rohani, N., Hao, L. L., Alexis, M. S., Joughin, B. A., Krismer, K., Moufarrej, M. N., et al. (2019). Acidification of tumor at stromal boundaries drives transcriptome alterations associated with aggressive phenotypes. Cancer Research, 79(8), 1952-1966. https://doi.org/10.1158/0008-5472.Can-18-1604

85. Davenport, H. W. (1974). The ABC of Acid-Base Chemistry (6ed.): The University of Chicago Press.

86. Kondo, A., Yamamoto, S., Nakaki, R., Shimamura, T., Hamakubo, T., Sakai, J., et al. (2017). Extracellular acidic pH activates the sterol regulatory element-binding protein 2 to promote tumor progression. Cell Reports, 18(9), 2228-2242. https://doi. org/10.1016/j.celrep.2017.02.006

87. Hofschroer, V., Koch, K. A., Ludwig, F. T., Friedl, P., Oberleithner, H., Stock, C., et al. (2017). Extracellular protonation modulates cell-cell interaction mechanics and tissue invasion in human melanoma cells. Scientific Reports, 7, ARTN 42369. https://doi. org/10.1038/srep42369

88. Pillai, S. R., Damaghi, M., Marunaka, Y., Spugnini, E. P., Fais, S., \& Gillies, R. J. (2019). Causes, consequences, and therapy of tumors acidosis. Cancer and Metastasis Reviews, 38(1-2), 205-222. https://doi.org/10.1007/s10555-019-09792-7

89. Webb, B. A., Chimenti, M., Jacobson, M. P., \& Barber, D. L. (2011). Dysregulated pH: A perfect storm for cancer progression. Nature Reviews Cancer, 11(9), 671-677. https://doi.org/10.1038/nrc3110

90. Corbet, C., \& Feron, O. (2017). Tumour acidosis: From the passenger to the driver's seat. Nature Reviews Cancer, 17(10), 577-593. https://doi.org/10.1038/nrc.2017.77

91. Wojtkowiak, J. W., Verduzco, D., Schramm, K. J., \& Gillies, R. J. (2011). Drug resistance and cellular adaptation to tumor acidic pH microenvironment. Molecular Pharmaceutics, 8(6), 2032-2038. https://doi.org/10.1021/mp200292c

92. Zhou, Z. H., Song, J. W., Li, W., Liu, X., Cao, L., Wan, L. M., et al. (2017). The acid-sensing ion channel, ASIC2, promotes invasion and metastasis of colorectal cancer under acidosis by activating the calcineurin/NFAT1 axis. Journal of Experimental \& Clinical Cancer Research, 36(1), 130. https://doi.org/10.1186/ s13046-017-0599-9
93. Hu, P., Li, S., Tian, N., Wu, F., Hu, Y., Li, D., et al. (2019). Acidosis enhances the self-renewal and mitochondrial respiration of stem cell-like glioma cells through CYP24A1-mediated reduction of vitamin D. Cell Death \& Disease, 10(1), 25. https:// doi.org/10.1038/s41419-018-1242-1

94. Lamonte, G., Tang, X., Chen, J. L., Wu, J., Ding, C. K., Keenan, M. M., et al. (2013). Acidosis induces reprogramming of cellular metabolism to mitigate oxidative stress. Cancer and Metabolism, 1(1), 23. https://doi.org/10.1186/2049-3002-1-23

95. Peppicelli, S., Bianchini, F., Toti, A., Laurenzana, A., Fibbi, G., \& Calorini, L. (2015). Extracellular acidity strengthens mesenchymal stem cells to promote melanoma progression. Cell Cycle, 14(19), 3088-3100. https://doi.org/10.1080/15384101.2015. 1078032

96. Tang, X., Lucas, J. E., Chen, J. L., LaMonte, G., Wu, J., Wang, M. C., et al. (2012). Functional interaction between responses to lactic acidosis and hypoxia regulates genomic transcriptional outputs. Cancer Research, 72(2), 491-502. https://doi.org/10. 1158/0008-5472.CAN-11-2076

97. Menard, J. A., Christianson, H. C., Kucharzewska, P., BourseauGuilmain, E., Svensson, K. J., Lindqvist, E., et al. (2016). Metastasis Stimulation by hypoxia and acidosis-induced extracellular lipid uptake is mediated by proteoglycan-dependent endocytosis. Cancer Research, 76(16), 4828-4840. https://doi.org/10.1158/ 0008-5472.CAN-15-2831

98. John, S., Sivakumar, K. C., \& Mishra, R. (2017). Extracellular Proton concentrations impacts LN229 glioblastoma tumor cell fate via differential modulation of surface lipids. Frontiers in Oncology, 7, 20. https://doi.org/10.3389/fonc.2017.00020

99. Moellering, R. E., Black, K. C., Krishnamurty, C., Baggett, B. K., Stafford, P., Rain, M., et al. (2008). Acid treatment of melanoma cells selects for invasive phenotypes. Clinical \& Experimental Metastasis, 25(4), 411-425. https://doi.org/10.1007/ s10585-008-9145-7

100. Sutoo, S., Maeda, T., Suzuki, A., \& Kato, Y. (2020). Adaptation to chronic acidic extracellular $\mathrm{pH}$ elicits a sustained increase in lung cancer cell invasion and metastasis. Clinical \& Experimental Metastasis, 37(1), 133-144. https://doi.org/10.1007/ s10585-019-09990-1

101. Zhou, Z. H., Wang, Q. L., Mao, L. H., Li, X. Q., Liu, P., Song, J. W., et al. (2019). Chromatin accessibility changes are associated with enhanced growth and liver metastasis capacity of acid-adapted colorectal cancer cells. Cell Cycle, 18(4), 511-522. https://doi.org/10.1080/15384101.2019.1578145

102. Logozzi, M., Mizzoni, D., Angelini, D. F., Di Raimo, R., Falchi, M., Battistini, L., et al. (2018). Microenvironmental pH and exosome levels interplay in human cancer cell lines of different histotypes. Cancers (Basel), 10(10), https://doi.org/10.3390/cance rs10100370.

103. Corbet, C., Pinto, A., Martherus, R., Santiago de Jesus, J. P., Polet, F., \& Feron, O. (2016). Acidosis drives the reprogramming of fatty acid metabolism in cancer cells through changes in mitochondrial and histone acetylation. Cell Metabolism, 24(2), 311-323. https://doi.org/10.1016/j.cmet.2016.07.003

104. Carmeliet, P., Dor, Y., Herbert, J. M., Fukumura, D., Brusselmans, K., Dewerchin, M., et al. (1998). Role of HIF-1alpha in hypoxia-mediated apoptosis, cell proliferation and tumour angiogenesis. Nature, 394(6692), 485-490. https://doi.org/10. $1038 / 28867$

105. Maxwell, P. H., Dachs, G. U., Gleadle, J. M., Nicholls, L. G., Harris, A. L., Stratford, I. J., et al. (1997). Hypoxia-inducible factor-1 modulates gene expression in solid tumors and influences both angiogenesis and tumor growth. Proceedings of the National Academy of Sciences of U S A, 94(15), 8104-8109. https://doi.org/10.1073/pnas.94.15.8104 
106. Khacho, M., Tarabay, M., Patten, D., Khacho, P., MacLaurin, J. G., Guadagno, J., et al. (2014). Acidosis overrides oxygen deprivation to maintain mitochondrial function and cell survival. Nature Communications, 5, ARTN 3550. https://doi.org/10.1038/ ncomms 4550

107. Gillies, R. J., Liu, Z., \& Bhujwalla, Z. (1994). 31P-MRS measurements of extracellular $\mathrm{pH}$ of tumors using 3-aminopropylphosphonate. American Journal of Physiology, 267(1 Pt 1), C195-203. https://doi.org/10.1152/ajpcell.1994.267.1.C195

108. Ward, K. M., Aletras, A. H., \& Balaban, R. S. (2000). A new class of contrast agents for MRI based on proton chemical exchange dependent saturation transfer (CEST). Journal of Magnetic Resonance, 143(1), 79-87. https://doi.org/10.1006/ jmre.1999.1956

109. Chen, M. M., Chen, C. Y., Shen, Z. W., Zhang, X. L., Chen, Y. Z., Lin, F. F., et al. (2017). Extracellular pH is a biomarker enabling detection of breast cancer and liver cancer using CEST MRI. Oncotarget, 8(28), 45759-45767. https://doi.org/ 10.18632/oncotarget.17404

110. Coman, D., Huang, Y., Rao, J. U., De Feyter, H. M., Rothman, D. L., Juchem, C., et al. (2016). Imaging the intratumoralperitumoral extracellular $\mathrm{pH}$ gradient of gliomas. NMR in Biomedicine, 29(3), 309-319. https://doi.org/10.1002/nbm.3466

111. Murdter, T. E., Friedel, G., Backman, J. T., McClellan, M., Schick, M., Gerken, M., et al. (2002). Dose optimization of a doxorubicin prodrug (HMR 1826) in isolated perfused human lungs: Low tumor $\mathrm{pH}$ promotes prodrug activation by betaglucuronidase. Journal of Pharmacology and Experimental Therapeutics, 301(1), 223-228. https://doi.org/10.1124/jpet. 301.1.223

112. Thistlethwaite, A. J., Leeper, D. B., Moylan, D. J., \& Nerlinger, R. E. (1985). Ph distribution in human-tumors. International Journal of Radiation Oncology Biology Physics, 11(9), 16471652. https://doi.org/10.1016/0360-3016(85)90217-2

113. van Sluis, R., Bhujwalla, Z. M., Raghunand, N., Ballesteros, P., Alvarez, J., Cerdan, S., et al. (1999). In vivo imaging of extracellular $\mathrm{pH}$ using $1 \mathrm{H}$ MRSI. Magnetic Resonance in Medicine, 41(4), 743-750. https://doi.org/10.1002/(sici)15222594(199904)41:4\%3c743::aid-mrm13\%3e3.0.co;2-z

114. Anemone, A., Consolino, L., Conti, L., Irrera, P., Hsu, M. Y., Villano, D., et al. (2021). Tumour acidosis evaluated in vivo by MRI-CEST $\mathrm{pH}$ imaging reveals breast cancer metastatic potential. British Journal of Cancer, 124(1), 207-216. https://doi.org/ 10.1038/s41416-020-01173-0

115. Tang, Y. Y., Xiao, G., Shen, Z. W., Zhuang, C. Y., Xie, Y. D., Zhang, X. L., et al. (2020). Noninvasive detection of extracellular $\mathrm{pH}$ in human benign and malignant liver tumors using CEST MRI. Frontiers in Oncology, 10, ARTN 578985. https://doi.org/ 10.3389/fonc. 2020.578985

116. Ferrauto, G., Di Gregorio, E., Auboiroux, V., Petit, M., Berger, F., Aime, S., et al. (2018). CEST-MRI for glioma pH quantification in mouse model: Validation by immunohistochemistry. $N M R$ in Biomedicine, 31(11), e4005. https://doi.org/10.1002/nbm.4005

117. Liu, G., Li, Y., Sheth, V. R., \& Pagel, M. D. (2012). Imaging in vivo extracellular $\mathrm{pH}$ with a single paramagnetic chemical exchange saturation transfer magnetic resonance imaging contrast agent. Molecular Imaging, 11(1), 47-57.

118. Duwel, S., Hundshammer, C., Gersch, M., Feuerecker, B., Steiger, K., Buck, A., et al. (2017). Imaging of $\mathrm{pH}$ in vivo using hyperpolarized (13)C-labelled zymonic acid. Nature Communications, 8, 15126. https://doi.org/10.1038/ncomms 15126

119. Samouilov, A., Efimova, O. V., Bobko, A. A., Sun, Z., Petryakov, S., Eubank, T. D., et al. (2014). In vivo proton-electron doubleresonance imaging of extracellular tumor $\mathrm{pH}$ using an advanced nitroxide probe. Analytical Chemistry, 86(2), 1045-1052. https:// doi.org/10.1021/ac402230h
120. Komarov, D. A., Ichikawa, Y., Yamamoto, K., Stewart, N. J., Matsumoto, S., Yasui, H., et al. (2018). In vivo extracellular ph mapping of tumors using electron paramagnetic resonance. Analytical Chemistry, 90(23), 13938-13945. https://doi.org/10.1021/ acs.analchem. 8 b03328

121. Chen, L. Q., \& Pagel, M. D. (2015). Evaluating pH in the extracellular tumor microenvironment using CEST MRI and other imaging methods.Advanced Radiology, 2015https://doi.org/10. $1155 / 2015 / 206405$

122. Ferrara, N., Gerber, H. P., \& LeCouter, J. (2003). The biology of VEGF and its receptors. Nature Medicine, 9(6), 669-676. https:// doi.org/10.1038/nm0603-669

123. Dirscherl, K., Schlapfer, M., Roth Z'graggen, B., Wenger, R. H., Booy, C., Flury-Frei, R., et al. (2020). Hypoxia sensing by hepatic stellate cells leads to VEGF-dependent angiogenesis and may contribute to accelerated liver regeneration. Scientific Reports, 10(1), 4392. https://doi.org/10.1038/s41598-020-60709-9

124. Sandner, P., Wolf, K., Bergmaier, U., Gess, B., \& Kurtz, A. (1997). Induction of VEGF and VEGF receptor gene expression by hypoxia: Divergent regulation in vivo and in vitro. Kidney International, 51(2), 448-453. https://doi.org/10.1038/ki.1997. 60

125. Gu, J. W., \& Adair, T. H. (1997). Hypoxia-induced expression of VEGF is reversible in myocardial vascular smooth muscle cells. American Journal of Physiology, 273(2 Pt 2), H628-633. https:// doi.org/10.1152/ajpheart.1997.273.2.H628

126. Garcia-Roman, J., Ibarra-Sanchez, A., Lamas, M., \& Gonzalez Espinosa, C. (2010). VEGF secretion during hypoxia depends on free radicals-induced Fyn kinase activity in mast cells. Biochemical and Biophysical Research Communications, 401(2), 262-267. https://doi.org/10.1016/j.bbrc.2010. 09.047

127. Liu, Y., Cox, S. R., Morita, T., \& Kourembanas, S. (1995). Hypoxia regulates vascular endothelial growth factor gene expression in endothelial cells. Identification of a 5' enhancer. Circulation Research, 77(3), 638-643. https://doi.org/10.1161/ 01.res.77.3.638

128. Kimura, H., Braun, R. D., Ong, E. T., Hsu, R., Secomb, T. W., Papahadjopoulos, D., et al. (1996). Fluctuations in red cell flux in tumor microvessels can lead to transient hypoxia and reoxygenation in tumor parenchyma. Cancer Research, 56(23), 5522-5528.

129. Braun, R. D., Lanzen, J. L., \& Dewhirst, M. W. (1999). Fourier analysis of fluctuations of oxygen tension and blood flow in R3230Ac tumors and muscle in rats. American Journal of Physiology, 277(2), H551-568. https://doi.org/10.1152/ajpheart. 1999.277.2.H551

130. Baudelet, C., Cron, G. O., Ansiaux, R., Crokart, N., DeWever, J., Feron, O., et al. (2006). The role of vessel maturation and vessel functionality in spontaneous fluctuations of T2*-weighted GRE signal within tumors. NMR in Biomedicine, 19(1), 69-76. https:// doi.org/10.1002/nbm.1002

131. Hurwitz, H., Fehrenbacher, L., Novotny, W., Cartwright, T., Hainsworth, J., Heim, W., et al. (2004). Bevacizumab plus irinotecan, fluorouracil, and leucovorin for metastatic colorectal cancer. New England Journal of Medicine, 350(23), 2335-2342. https://doi.org/10.1056/NEJMoa032691

132. Escudier, B., Eisen, T., Stadler, W. M., Szczylik, C., Oudard, S., Siebels, M., et al. (2007). Sorafenib in advanced clear-cell renal-cell carcinoma. New England Journal of Medicine, 356(2), 125-134. https://doi.org/10.1056/NEJMoa060655

133. Ellis, L. M., \& Hicklin, D. J. (2008). VEGF-targeted therapy: Mechanisms of anti-tumour activity. Nature Reviews Cancer, 8(8), 579-591. https://doi.org/10.1038/nrc2403

134. Jain, R. K. (2005). Normalization of tumor vasculature: An emerging concept in antiangiogenic therapy. Science, 307(5706), 58-62. https://doi.org/10.1126/science.1104819 
135. Fiorillo, M., Lamb, R., Tanowitz, H. B., Mutti, L., KrsticDemonacos, M., Cappello, A. R., et al. (2016). Repurposing atovaquone: Targeting mitochondrial complex III and OXPHOS to eradicate cancer stem cells. Oncotarget, 7(23), 34084-34099. https://doi.org/10.18632/oncotarget.9122

136. Shriwas, P., Roberts, D., Li, Y., Wang, L., Qian, Y., Bergmeier, S., et al. (2021). A small-molecule pan-class I glucose transporter inhibitor reduces cancer cell proliferation in vitro and tumor growth in vivo by targeting glucose-based metabolism. Cancer Metabolism, 9(1), 14. https://doi.org/10.1186/ s40170-021-00248-7

137. Walters, D. K., Arendt, B. K., \& Jelinek, D. F. (2013). CD147 regulates the expression of MCT1 and lactate export in multiple myeloma cells. Cell Cycle, 12(19), 3175-3183. https://doi.org/ $10.4161 / \mathrm{cc} .26193$

138. Miranda-Goncalves, V., Goncalves, C. S., Granja, S., Vieira de Castro, J., Reis, R. M., Costa, B. M., et al. (2021). MCT1 Is a new prognostic biomarker and its therapeutic inhibition boosts response to temozolomide in human glioblastoma. Cancers (Basel), 13(14), https://doi.org/10.3390/cancers13143468.

139. Lee, S. H., McIntyre, D., Honess, D., Hulikova, A., PachecoTorres, J., Cerdan, S., et al. (2018). Carbonic anhydrase IX is a $\mathrm{pH}$-stat that sets an acidic tumour extracellular $\mathrm{pH}$ in vivo. British Journal of Cancer, 119(5), 622-630. https://doi.org/10. 1038/s41416-018-0216-5

140. Hulikova, A., Aveyard, N., Harris, A. L., Vaughan-Jones, R. D., \& Swietach, P. (2014). Intracellular carbonic anhydrase activity sensitizes cancer cell $\mathrm{pH}$ signaling to dynamic changes in CO2 partial pressure. Journal of Biological Chemistry, 289(37), 25418-25430. https://doi.org/10.1074/jbc.M114.547844

141. Liskova, V., Hudecova, S., Lencesova, L., Iuliano, F., Sirova, M., Ondrias, K., et al. (2019). Type 1 sodium calcium exchanger forms a complex with carbonic anhydrase IX and via reverse mode activity contributes to $\mathrm{pH}$ control in hypoxic tumors. Cancers (Basel), 11(8), https://doi.org/10.3390/cancers11081139.

142. Kajanova, I., Zatovicova, M., Jelenska, L., Sedlakova, O., Barathova, M., Csaderova, L., et al. (2020). Impairment of carbonic anhydrase IX ectodomain cleavage reinforces tumorigenic and metastatic phenotype of cancer cells. British Journal of Cancer, 122(11), 1590-1603. https://doi.org/10.1038/s41416-020-0804-z

143. Grandane, A., Nocentini, A., Werner, T., Zalubovskis, R., \& Supuran, C. T. (2020). Benzoxepinones: A new isoform-selective class of tumor associated carbonic anhydrase inhibitors. Bioorganic \& Medicinal Chemistry, 28(11), 115496. https://doi.org/ 10.1016/j.bmc.2020.115496

144. McDonald, P. C., Chafe, S. C., Brown, W. S., Saberi, S., Swayampakula, M., Venkateswaran, G., et al. (2019). Regulation of $\mathrm{pH}$ by carbonic anhydrase 9 mediates survival of pancreatic cancer cells with activated KRAS in response to hypoxia. Gastroenterology, 157(3), 823-837. https://doi.org/10.1053/j.gastro.2019. 05.004

145. Mboge, M. Y., Chen, Z., Khokhar, D., Wolff, A., Ai, L., Heldermon, C. D., et al. (2019). A non-catalytic function of carbonic anhydrase IX contributes to the glycolytic phenotype and $\mathrm{pH}$ regulation in human breast cancer cells. The Biochemical Journal, 476(10), 1497-1513. https://doi.org/10.1042/BCJ20190177

146. Swietach, P. (2019). What is $\mathrm{pH}$ regulation, and why do cancer cells need it? Cancer and Metastasis Reviews, 38(1-2), 5-15. https://doi.org/10.1007/s10555-018-09778-x

147. Xie, J. S., Wu, H., Dai, C. Y., Pan, Q. R., Ding, Z. H., Hu, D. Q., et al. (2014). Beyond Warburg effect - Dual metabolic nature of cancer cells. Scientific Reports, 4, ARTN 4927. https://doi.org/ 10.1038/srep04927

148. Oz, T., Guvenek, A., Yildiz, S., Karaboga, E., Tamer, Y. T., Mumcuyan, N., et al. (2014). Strength of selection pressure is an important parameter contributing to the complexity of antibiotic resistance evolution. Molecular Biology and Evolution, 31(9), 2387-2401. https://doi.org/10.1093/molbev/msu191

149. Thomas, F., Ujvari, B., Renaud, F., \& Vincent, M. (2017). Cancer adaptations: Atavism, de novo selection, or something in between? Bioessays, 39(8), https://doi.org/10.1002/bies.20170 0039.

150. Muller, A. W. J. (2017). Cancer is an adaptation that selects in animals against energy dissipation. Medical Hypotheses, 104. 104-115. https://doi.org/10.1016/j.mehy.2017.05.030

151. Leroi, A. M., Koufopanou, V., \& Burt, A. (2003). Cancer selection. Nature Reviews Cancer, 3(3), 226-231. https://doi.org/10. 1038/nrc1016

152. Voskarides, K. (2018). Group selection may explain cancer predisposition and other human traits' evolution. Journal of Molecular Evolution, 86(3-4), 184-186. https://doi.org/10.1007/ s00239-018-9841-0

153. Persi, E., Wolf, Y. I., Horn, D., Ruppin, E., Demichelis, F., Gatenby, R. A., et al. (2021). Mutation-selection balance and compensatory mechanisms in tumour evolution. Nature Reviews Genetics, 22(4), 251-262. https://doi.org/10.1038/ s41576-020-00299-4

154. Fortunato, A., Boddy, A., Mallo, D., Aktipis, A., Maley, C. C., \& Pepper, J. W. (2017). Natural selection in cancer biology: From molecular snowflakes to trait hallmarks. Cold Spring Harb Perspect Med, 7(2), https://doi.org/10.1101/cshperspect.a029652.

155. Klein, C. A. (2013). Selection and adaptation during metastatic cancer progression. Nature, 501(7467), 365-372. https://doi.org/ 10.1038 /nature 12628

156. Martincorena, I., Raine, K. M., Gerstung, M., Dawson, K. J., Haase, K., Van Loo, P., et al. (2017). Universal patterns of selection in cancer and somatic tissues. Cell, 171(5), 1029-1041 e1021. https://doi.org/10.1016/j.cell.2017.09.042

157. Robey, I. F., Baggett, B. K., Kirkpatrick, N. D., Roe, D. J., Dosescu, J., Sloane, B. F., et al. (2009). Bicarbonate increases tumor $\mathrm{pH}$ and inhibits spontaneous metastases. Cancer Research, 69(6), 2260-2268. https://doi.org/10.1158/0008-5472.CAN-07-5575

158. Potzl, J., Roser, D., Bankel, L., Homberg, N., Geishauser, A., Brenner, C. D., et al. (2017). Reversal of tumor acidosis by systemic buffering reactivates NK cells to express IFN-gamma and induces NK cell-dependent lymphoma control without other immunotherapies. International Journal of Cancer, 140(9), 2125-2133. https://doi.org/10.1002/ijc.30646

159. Ibrahim-Hashim, A., Cornnell, H. H., Abrahams, D., Lloyd, M., Bui, M., Gillies, R. J., et al. (2012). Systemic buffers inhibit carcinogenesis in TRAMP mice. Journal of Urology, 188(2), 624-631. https://doi.org/10.1016/j.juro.2012.03.113

160. Hamaguchi, R., Narui, R., \& Wada, H. (2020). Effects of alkalization therapy on chemotherapy outcomes in metastatic or recurrent pancreatic cancer. Anticancer Research, 40(2), 873-880. https://doi.org/10.21873/anticanres.14020

161. Yang, M., Zhong, X., \& Yuan, Y. (2020). Does baking soda function as a magic bullet for patients with cancer? A mini review. Integrative Cancer Therapies, 19, 1534735420922579. https:// doi.org/10.1177/1534735420922579

162. Chao, M., Wu, H., Jin, K., Li, B., Wu, J., Zhang, G., et al 2016 A nonrandomized cohort and a randomized study of local control of large hepatocarcinoma by targeting intratumoral lactic acidosis. ELife 5https://doi.org/10.7554/eLife.15691

163. Ibrahim-Hashim, A., Abrahams, D., Enriquez-Navas, P. M., Luddy, K., Gatenby, R. A., \& Gillies, R. J. (2017). Tris-base buffer: A promising new inhibitor for cancer progression and metastasis. Cancer Medicine, 6(7), 1720-1729. https://doi.org/ 10.1002/cam4.1032

164. Ibrahim Hashim, A., Cornnell, H. H., de Coelho Ribeiro, M. L., Abrahams, D., Cunningham, J., Lloyd, M., et al. (2011). Reduction of metastasis using a non-volatile buffer. Clinical \& 
Experimental Metastasis, 28(8), 841-849. https://doi.org/10. 1007/s10585-011-9415-7

165. Wong, W. Y., DeLuca, C. I., Tian, B., Wilson, I., Molund, S., Warriar, N., et al. (2005). Urease-induced alkalinization of extracellular $\mathrm{pH}$ and its antitumor activity in human breast and lung cancers. Journal of Experimental Therapeutics \& Oncology, 5(2), 93-99.

166. Damgaci, S., Ibrahim-Hashim, A., Enriquez-Navas, P. M., PilonThomas, S., Guvenis, A., \& Gillies, R. J. (2018). Hypoxia and acidosis: Immune suppressors and therapeutic targets. Immunology, 154(3), 354-362. https://doi.org/10.1111/imm.12917

167. Demotte, N., Stroobant, V., Courtoy, P. J., Van Der Smissen, P., Colau, D., Luescher, I. F., et al. (2008). Restoring the association of the $\mathrm{T}$ cell receptor with CD8 reverses anergy in human tumorinfiltrating lymphocytes. Immunity, 28(3), 414-424. https://doi. org/10.1016/j.immuni.2008.01.011

168. Calcinotto, A., Filipazzi, P., Grioni, M., Iero, M., De Milito, A., Ricupito, A., et al. (2012). Modulation of microenvironment acidity reverses anergy in human and murine tumor-infiltrating T lymphocytes. Cancer Research, 72(11), 2746-2756. https:// doi.org/10.1158/0008-5472.CAN-11-1272

169. Wu, H., Estrella, V., Beatty, M., Abrahams, D., El-Kenawi, A., Russell, S., et al. (2020). T-cells produce acidic niches in lymph nodes to suppress their own effector functions. Nature Communications, 11(1), 4113. https://doi.org/10.1038/ s41467-020-17756-7

170. Tong, L., Yue, P., Yang, Y., Huang, J., Zeng, Z., \& Qiu, W. (2021). Motility and mechanical properties of dendritic cells deteriorated by extracellular acidosis. Inflammation, 44(2), 737-745. https://doi.org/10.1007/s10753-020-01373-z

171. Caslin, H. L., Abebayehu, D., Pinette, J. A., \& Ryan, J. J. (2021). Lactate is a metabolic mediator that shapes immune cell fate and function. Frontiers in Physiology, 12, 688485. https://doi.org/10. 3389/fphys.2021.688485

172. Hoque, R., Farooq, A., Ghani, A., Gorelick, F., \& Mehal, W. Z. (2014). Lactate reduces liver and pancreatic injury in Toll-like receptor- and inflammasome-mediated inflammation via GPR81mediated suppression of innate immunity. Gastroenterology, 146(7), 1763-1774. https://doi.org/10.1053/j.gastro.2014.03.014

173. Selleri, S., Bifsha, P., Civini, S., Pacelli, C., Dieng, M. M., Lemieux, W., et al. (2016). Human mesenchymal stromal cellsecreted lactate induces M2-macrophage differentiation by metabolic reprogramming. Oncotarget, 7(21), 30193-30210. https:// doi.org/10.18632/oncotarget.8623

174. Paolini, L., Adam, C., Beauvillain, C., Preisser, L., Blanchard, S., Pignon, P., et al. (2020). Lactic acidosis together with GM-CSF and M-CSF induces human macrophages toward an inflammatory protumor phenotype. Cancer Immunology Research, 8(3), 383-395. https://doi.org/10.1158/2326-6066.CIR-18-0749

175. Nowell, P. C. (1976). The clonal evolution of tumor cell populations. Science, 194(4260), 23-28. https://doi.org/10.1126/scien ce. 959840

176. Wolfl, B., te Rietmole, H., Salvioli, M., Kaznatcheev, A., Thuijsman, F., Brown, J. S., et al. (2021). The contribution of evolutionary game theory to understanding and treating cancer. Dynamic Games and Applications. https://doi.org/10.1007/ s13235-021-00397-w

177. Navin, N. E. (2014). Tumor evolution in response to chemotherapy: Phenotype versus genotype. Cell Reports, 6(3), 417-419. https://doi.org/10.1016/j.celrep.2014.01.035

178. Damjanov, I., \& Fan, F. (2013). Cancer grading manual (Second edition. ed.). New York: Springer

179. Risom, T., Langer, E. M., Chapman, M. P., Rantala, J., Fields, A. J., Boniface, C., et al. (2018). Differentiation-state plasticity is a targetable resistance mechanism in basal-like breast cancer. Nature Communications, 9, ARTN 3815. https://doi.org/10.1038/ s41467-018-05729-w

180. Daveau, C., Baulies, S., Lalloum, M., Bollet, M., Sigal-Zafrani, B., Sastre, X., et al. (2014). Histological grade concordance between diagnostic core biopsy and corresponding surgical specimen in HR-positive/HER2-negative breast carcinoma. British Journal of Cancer, 110(9), 2195-2200. https://doi.org/10.1038/ bjc. 2014.143

181. Sotiriou, C., Wirapati, P., Loi, S., Harris, A., Fox, S., Smeds, J., et al. (2006). Gene expression profiling in breast cancer: Understanding the molecular basis of histologic grade to improve prognosis. Journal of the National Cancer Institute, 98(4), 262-272. https://doi.org/10.1093/jnci/djj052

182. Orgogozo, V., Morizot, B., \& Martin, A. (2015). The differential view of genotype-phenotype relationships. Frontiers in Genetics, 6, ARTN 179. https://doi.org/10.3389/fgene.2015.00179

183. Aynaud, M. M., Mirabeau, O., Gruel, N., Grossetete, S., Boeva, V., Durand, S., et al. (2020). Transcriptional programs define intratumoral heterogeneity of Ewing sarcoma at single-cell resolution. Cell Reports, 30(6), 1767-1779 e1766. https://doi.org/10. 1016/j.celrep.2020.01.049

184. Kinker, G. S., Greenwald, A. C., Tal, R., Orlova, Z., Cuoco, M. S., McFarland, J. M., et al. (2020). Pan-cancer single-cell RNA-seq identifies recurring programs of cellular heterogeneity. Nature Genetics, 52(11), 1208-+. https://doi.org/10.1038/ s41588-020-00726-6

185. Wu, F. Y., Fan, J., He, Y. Y., Xiong, A. W., Yu, J., Li, Y. X., et al. (2021). Single-cell profiling of tumor heterogeneity and the microenvironment in advanced non-small cell lung cancer. Nature Communications, 12(1), ARTN 2540. https://doi.org/10. 1038/s41467-021-22801-0

186. Papalexi, E., \& Satija, R. (2018). Single-cell RNA sequencing to explore immune cell heterogeneity. Nature Reviews Immunology, 18(1), 35-45. https://doi.org/10.1038/nri.2017.76

187. Kim, J. K., Kolodziejczyk, A. A., Illicic, T., Teichmann, S. A., \& Marioni, J. C. (2015). Characterizing noise structure in singlecell RNA-seq distinguishes genuine from technical stochastic allelic expression. Nature Communications, 6, ARTN 8687. https://doi.org/10.1038/ncomms9687

188. Zhang, R. Y., Atwal, G. S., \& Lim, W. K. (2021). Noise regularization removes correlation artifacts in single-cell RNA-seq data preprocessing. Patterns, 2(3), ARTN 100211. https://doi.org/10. 1016/j.patter.2021.100211

189. Wang, S., Ji, F., Li, Z., \& Xue, M. (2019). Fluorescence imagingbased methods for single-cell protein analysis. Analytical and Bioanalytical Chemistry, 411(19), 4339-4347. https://doi.org/ 10.1007/s00216-019-01694-5

190. Moore, T. A., Lie, A., \& Young, E. W. K. (2018). Integrating population heterogeneity indices with microfluidic cell-based assays. Slas Discovery, 23(5), 459-473. https://doi.org/10.1177/ 2472555217738533

191. Ma, M., Bordignon, P., Dotto, G. P., \& Pelet, S. (2020). Visualizing cellular heterogeneity by quantifying the dynamics of MAPK activity in live mammalian cells with synthetic fluorescent biosensors. Heliyon, 6(12), e05574. https://doi.org/10.1016/j.heliy on.2020.e 05574

Publisher's Note Springer Nature remains neutral with regard to jurisdictional claims in published maps and institutional affiliations. 